\title{
Rancang Bangun Edugame "History of Shodanco Supriyadi”: Sejarah Perlawanan Pasukan PETA Blitar Terhadap Jepang
}

http://dx.doi.org/10.28932/jutisi.v6i1.1979

\author{
Philips Denny Azarya ${ }^{\# 1}$, Pandi ${ }^{\# 2}$, Yohannes ${ }^{\# 3}$, Yoannita ${ }^{\text {ब\#4 }}$ \\ ${ }^{\#}$ Teknik Informatika, STMIK Global Informatika MDP \\ Jalan Rajawali No.14, Palembang \\ ${ }^{1}$ philipsdennyazaryaegmail.com \\ ${ }^{2}$ pandisu55egmail.com \\ ${ }^{3}$ yohannesmasterous@mdp.ac.id \\ ${ }^{4}$ yoannita@mdp.ac.id
}

\begin{abstract}
Games are not only for entertainment but it can be a means for learning. Historical subjects are often considered boring and uninteresting lessons because there are no innovations to attract students' curiosity. Therefore, a learning media was created and an introduction to the history of the resistance of the Blitar PETA forces through an adventure edugame. The methodology used is three increments iteration, each of which consists of analysis, design, code, and test phases. The game design uses Unity 3D as a tool. Evaluation was carried out by performing unit testing, system testing, and acceptance testing. Based on the evaluation results, it was found that the edugame application that developed was able to assist students in introducing the history of the resistance figure of Blitar PETA named Supriyadi.
\end{abstract}

Keywords-android; edugame; hero; history

\section{Pendahuluan}

Kecanggihan teknologi pada saat ini sangat memikat kalangan generasi millenial. Dengan teknologi yang terus maju dan berkembang, ponsel yang dulu biasa digunakan hanya untuk mengirimkan pesan teks dan suara sekarang banyak bermunculan sebagai ponsel pintar atau smartphone. Sekarang hampir semua kalangan menggunakan smartphone, berdasarkan hasil survey [1] $65,34 \%$ adalah kalangan remaja yang berumur 9-19 tahun. Saat ini game telah banyak tersebar pada perangkat smartphone, berdasarkan hasil survey [1] $77,41 \%$ digunakan untuk hiburan dan 20,28\% untuk belajar. Hal ini membuat sebagian orang tua khawatir jika anaknya lebih memilih atau menghabiskan waktu bermain game daripada belajar.
Game merupakan suatu alat yang sangat berpengaruh bagi kehidupan dan perkembangan teknologi yang ada. Game merupakan sesuatu yang tidak dapat terpisahkan bagi kehidupan khususnya bagi anak-anak, karena game dapat menyebabkan kecanduan kepada orang yang memainkannya, serta dapat menjadi hiburan atau alat refreshing penghilang kebosanan dari segala rutinitas keseharian yang telah dilalui [2]. Munculnya berbagai macam game, termasuk game edukasi juga dipengaruhi oleh perkembangannya teknologi yang semakin canggih di dunia ini.

Game edukasi mengenai tokoh pahlawan telah ada beberapa yang diangkat dalam sebuah game. Salah satu tokoh yang pernah diangkat dalam sebuah game adalah Kapitan Pattimura [3], sejarah tokoh - tokoh yang terdapat pada perang Surabaya seperti Bung Tomo [4], Ir. Soekarno, Jendral Soedirman, Gatot Soebroto, Jendral A.H. Nasution [5]. Dari sekian banyak tokoh pahlawan yang telah membela tanah air Indonesia, masih banyak tokoh pahlawan yang belum diangkat dalam sebuah game, salah satunya adalah Shodanco Supriyadi.

Terlepas dari segala kekurangan, game tidak hanya untuk hiburan semata melainkan game juga dapat menjadi salah satu sarana pembelajaran terutama bagi anak-anak yang masih menempuh pendidikan khususnya mata pelajaran sejarah. Mata pelajaran sejarah seringkali dianggap pelajaran yang membosankan dan tidak menarik dikarenakan masih menggunakan cara konvensional yang tidak ada inovasi untuk memikat keingintahuan siswa untuk mempelajari sejarah sehingga informasi sejarah yang didapat mudah terlupakan. Sejarah di Indonesia sangat banyak salah satunya penjajahan Jepang di 
Indonesia khususnya perlawanan PETA Blitar, dimana penjajahan Jepang merupakan penjajahan yang paling kejam dan brutal dibandingkan dengan Belanda [6], jika dilihat dari segi manfaat sejarah khususnya pada masa perlawanan PETA Blitar selain sebagai sumber pengetahuan juga sebagai edukatif yang dapat menjadi guru kehidupan, guna inspiratif untuk menaikkan moral generasi muda, menumbuhkan semangat dan rasa persatuan yang erat [7].

Berdasarkan hasil wawancara ke beberapa sekolah di kota Palembang didapatkan tokoh yang paling penting pada perlawanan pasukan PETA Blitar adalah Shodanco Supriyadi, tokoh Shodanco Supriyadi di kota Palembang sedikit yang mengenal, kenapa harus mengenal tokoh Shodanco Supriyadi karena ia merupakan pahlawan nasional, dan pada perlawanan pasukan PETA Blitar memberikan pengaruh yang besar bagi rakyat Indonesia.

Terdapat beberapa perancangan edugame terdahulu di bidang sejarah di Indonesia. Contohnya perancangan edugame sejarah dengan Unity 3D dengan tipe RPG (Role Playing Game) dan adventure mengenai sejarah Walisongo (Sunan Kalijaga) yang dapat digunakan sebagai alternatif pembelajaran untuk membantu dalam proses belajar, khususnya mengenai pelajaran sejarah Walisongo [8], game edukasi pengenalan peristiwa sejarah Permesta di Minahasa dengan jenis game petualangan [9].

Terdapat pula perancangan permainan edukatif pengenalan tokoh pahlawan nasional yang menggunakan quiz dan flip card dalam permainannya[10], pengembangan permainan edukatif mengenai pahlawan nasional yang bertipe puzzle berbasis Android menggunakan Construct 2 dengan metode pengembangan Multimedia Development Life Cycle (MDLC) untuk mengenalkan pahlawan nasional kepada masyarakat khususnya anak-anak dengan cara yang menyenangkan dan mudah diserap pada smartphone [11], dan perancangan aplikasi berbasis Android dengan tipe arcade mengenai pahlawan nasional Indonesia yang menggunakan perangkat lunak Unity 5 dan metodologi pembuatan game yang menggunakan GDLC (Game Development Life Cycle) [12].

Maka dari itu ada baiknya jika game tidak hanya dimainkan untuk hiburan semata melainkan juga dapat memberikan atau membantu anak-anak untuk bermain sambil belajar. Para penikmat game diharapkan tidak hanya bermain tetapi juga mendapatkan suatu dampak yang positif dari materi pendidikan yang dimasukkan ke dalam game supaya penikmat game tidak hanya sekedar bermain tetapi mendapatkan sebuah pengetahuan.

\section{Metodologi Penelitian}

Permainan dirancang untuk memperkenalkan sejarah perlawanan PETA Blitar terhadap kependudukan Jepang,
Agar dapat menjadi salah satu sarana pembelajaran tentang sejarah penjajahan Jepang di Indonesia khususnya perlawanan PETA Blitar tersebut dan tokoh Shodanco Supriyadi maka diperlukan analisis terkait perancangan permainan yang dilakukan. Perancangan tampilan game berbasis 3D dan lebih ditujukan untuk platform mobile game pada sistem operasi Android 5.1 atau lebih. Game dimainkan tanpa memerlukan koneksi internet.

Permainan dibuat bertipe single-player game dan mempunyai genre adventure dan FPS (First Person Shooting). Jenis game sangat banyak dan bervariasi, dari cara bermain, jumlah pemain di dalam game, media untuk memainkan game, jenis game berdasarkan tipe game yang biasa dimainkan di smartphone dan komputer [2]. Jenis game dapat dibedakan sebagai berikut [2]:

1. Adventure Games

Permainan ini mengutamakan masalah eksplorasi dan pemecahan teka-teki, namun terkadang meliputi masalah konseptual. Permainan petualangan yaitu sebuah cerita interaktif dimana pemain berperan sentral di dalam cerita itu sendiri [13]. Dalam permainan sendiri dimainkan melalui eksplorasi dan menyelesaikan tantangan. Contoh game seperti Fahrenheit: Indigo Prophecy, Assassin's Creed Pirates, Edge of Tomorrow, Modern Combat 5 Blackout, Neon shadow, dan sebagainya.

2. Action Games

Meliputi tantangan fisik, puzzle, races atau balapan, dan beberapa konflik. Dapat juga meliputi masalah ekonomi, seperti mengumpulkan benda-benda.

3. Real Time Strategy (RTS)

Game yang menyangkut taktik, logika, dan masalah strategi. Contohnya seperti game Age of empire dan Warcraft

4. Role Playing Games

Kebanyakan game jenis ini melibatkan masalah taktik, logika, dan eksplorasi atau penjelajahan. Contohnya seperti Final Fantasy, Ragnarok dan Lord of The Ring

5. Real World simulation.

Game ini meliputi permainan olahraga dan simulasi masalah kendaraan termasuk kendaraan militer. Contohnya seperti Championship Manager

6. Construction and Management

Game ini pada dasarnya adalah masalah ekonomi dan konseptual, Seperti game Roller Coaster Tycoon dan The Sims.

7. Puzzle Games

Difokuskan untuk memecahkan suatu masalah tertentu, hampir semua rintangan atau tantangan menyangkut masalah logika yang sering kali dibatasi oleh waktu. 


\section{Slide Scrolling Games}

Pada jenis game ini karakter dapat bergerak ke samping diikuti dengan gerakan background. Contohnya seperti Super Mario dan Metal Slug.

Permainan yang dirancang untuk pengenalan tokoh Shodanco Supriyadi ini bertipe adventure yang merupakan petualangan dari seorang anak yang bernama Leon yang masuk ke dalam game. Leon memerankan tokoh Shodanco Supriyadi yang merupakan salah satu tokoh paling penting pada pasukan PETA Blitar. Leon berpetualang untuk melakukan perlawanan terhadap Jepang. Permainan ini menggunakan sudut pandang orang pertama.

Perangkat lunak yang digunakan dalam pengembangan aplikasi adalah Unity versi 2018 dan untuk melakukan pengkodean program digunakan Visual Studio Community 2017 dengan bahasa pemrograman C\#. Unity adalah suatu game engine yang dapat digunakan untuk mengembangkan suatu permainan. Secara default Unity diatur untuk pembuatan game yang ber-genre FPS (First Person Shooting), namun Unity juga dapat digunakan untuk membangun atau membuat sebuah game yang bergenre RTS (Real Time Strategy), dan RPG (Role Playing Game). Unity dapat dikembangkan untuk multiplatform seperti Windows, Mac, Perangkat Android, iOS, PS3 dan juga WiiWare [14].

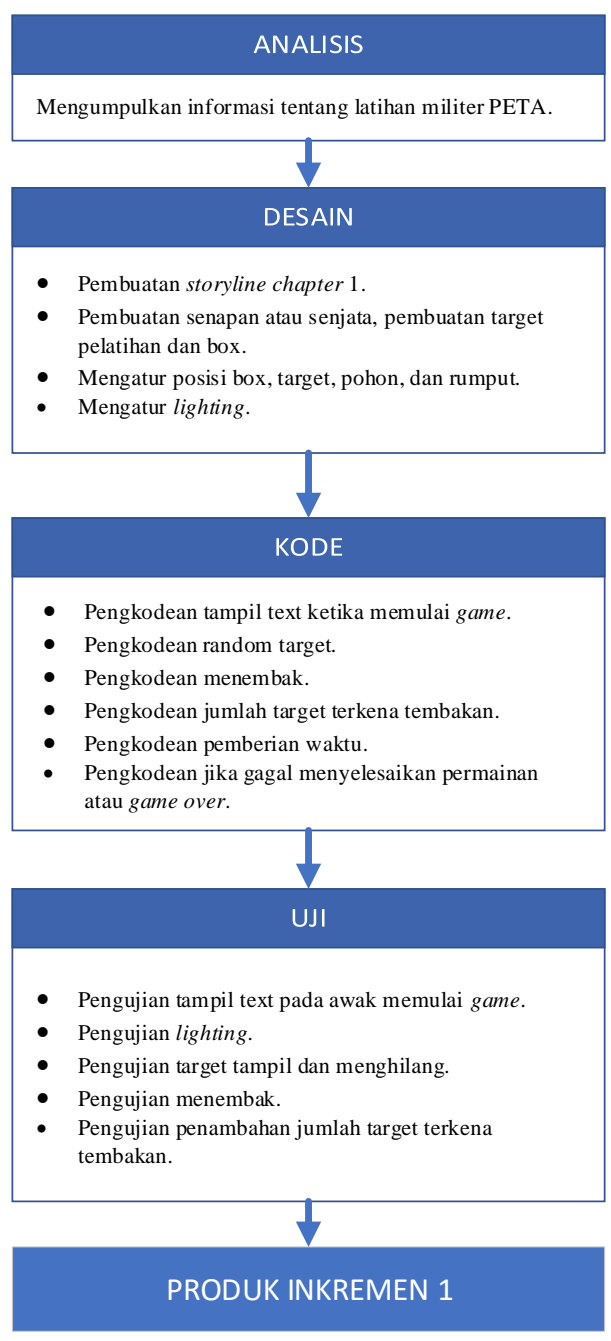

Gambar 1. Inkremen pertama

Model iterasi mengkombinasikan proses-proses pada model air terjun dan iterasi pada model prototipe [15] Model inkremental akan dibagi menjadi 3 inkremen yang akan menghasilkan bagian-bagian perangkat lunak yang sudah mengalami penambahan fungsi untuk setiap proses inkremennya. Inkremen masing-masing dapat dilihat pada Gambar 1 sampai dengan Gambar 3. 


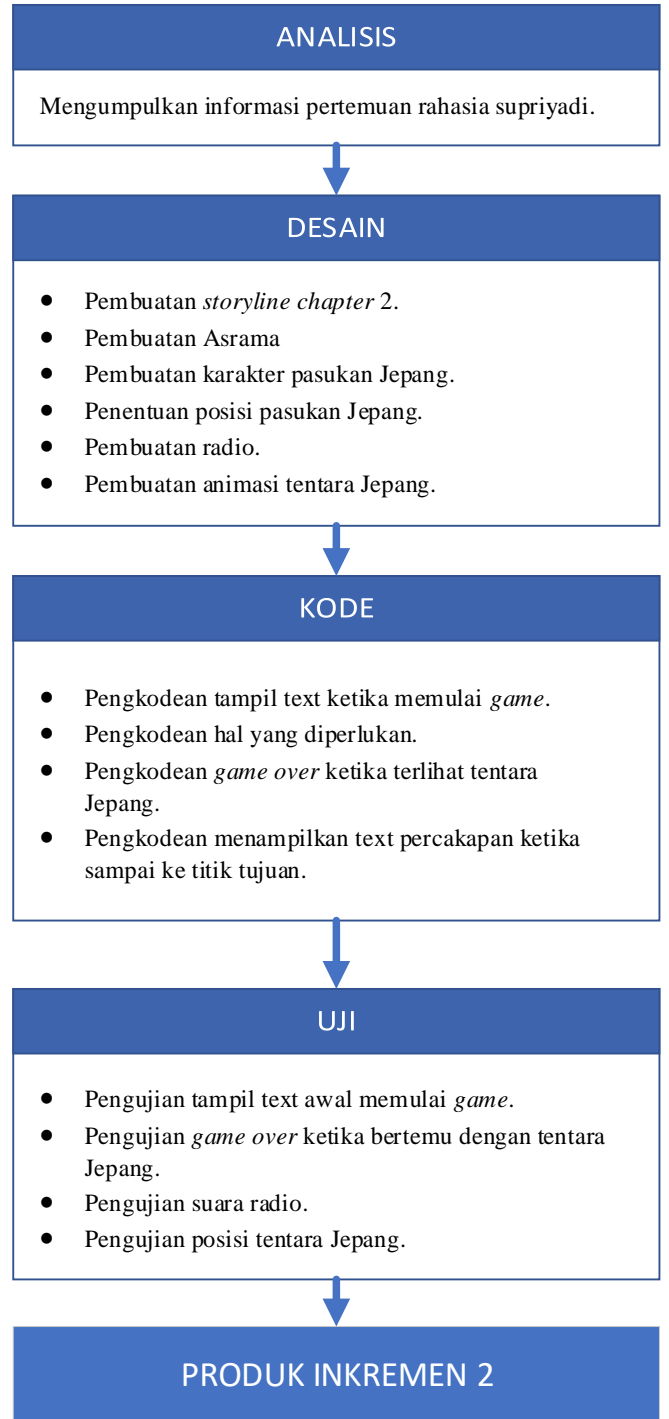

Gambar 2. Inkremen kedua

Dalam proses pembuatan masing-masing inkremen pada Gambar 1 sampai dengan Gambar 3 melalui beberapa tahapan yaitu:

\section{A. Analisis Kebutuhan}

Pada tahap ini dilakukan proses pengumpulan informasi atau data-data apa saja yang dibutuhkan dalam aplikasi melalui buku dan wawancara terhadap guru sejarah, baik tentang perangkat lunak yang akan dipakai, sejarah penjajahan Jepang di Indonesia khususnya perlawanan PETA Blitar dan jumlah misi yang akan diberikan pada edugame.

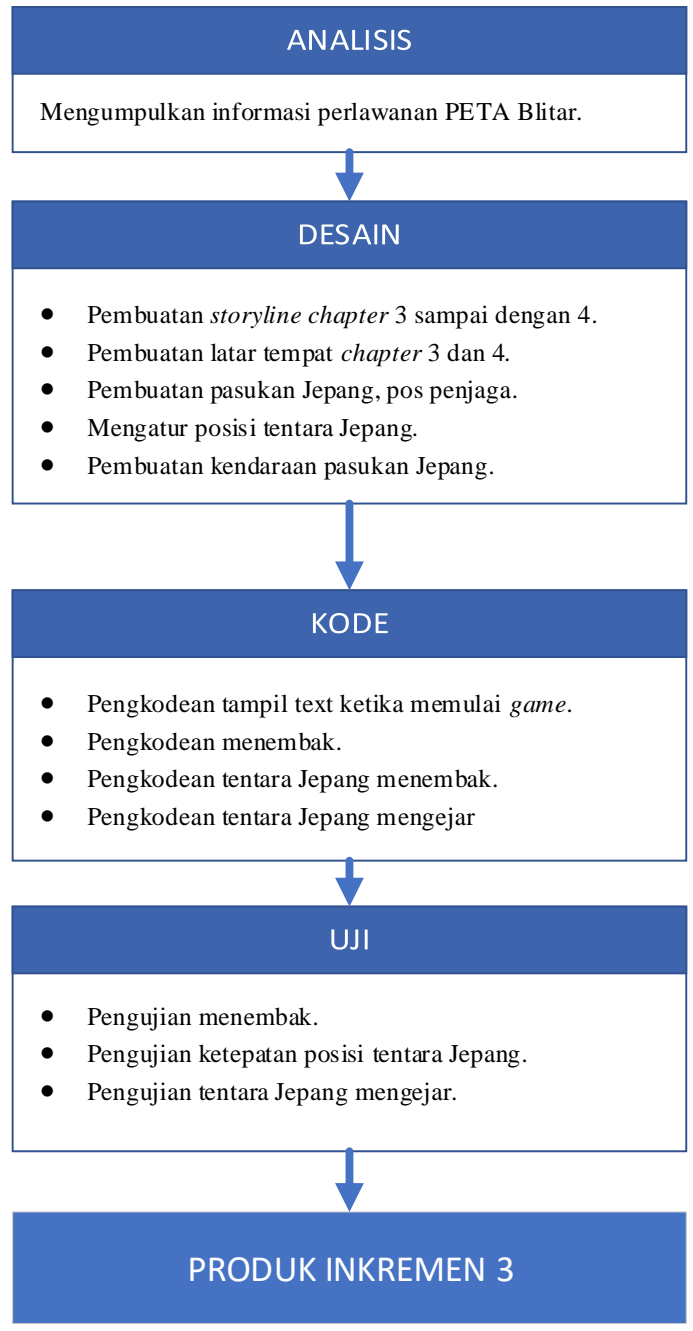

Gambar 3. Inkremen ketiga

\section{B. Desain}

Pada tahap ini dilakukan perencanaan alur dari edugame yang akan dibuat dengan membuat storyline, menganalisis alur dari sistem, dan membuat rancangan. Tahap ini akan mendesain tampilan menu, luas area permainan, letak objek-objek yang dibutuhkan pada setiap stage dengan Unity Game Engine.

Permainan ini merupakan sebuah game edukasi yang bertemakan tentang sejarah dari seorang pahlawan Indonesia yaitu Supriyadi. Alur Cerita utama diperlihatkan pada Tabel I. Di dalam permainan, pemain memainkan peran Supriyadi dari awal masuk organisasi PETA Blitar hingga ketika ia memimpin sebuah serangan terhadap pendudukan Jepang. 
TABEL I

STORYLINE

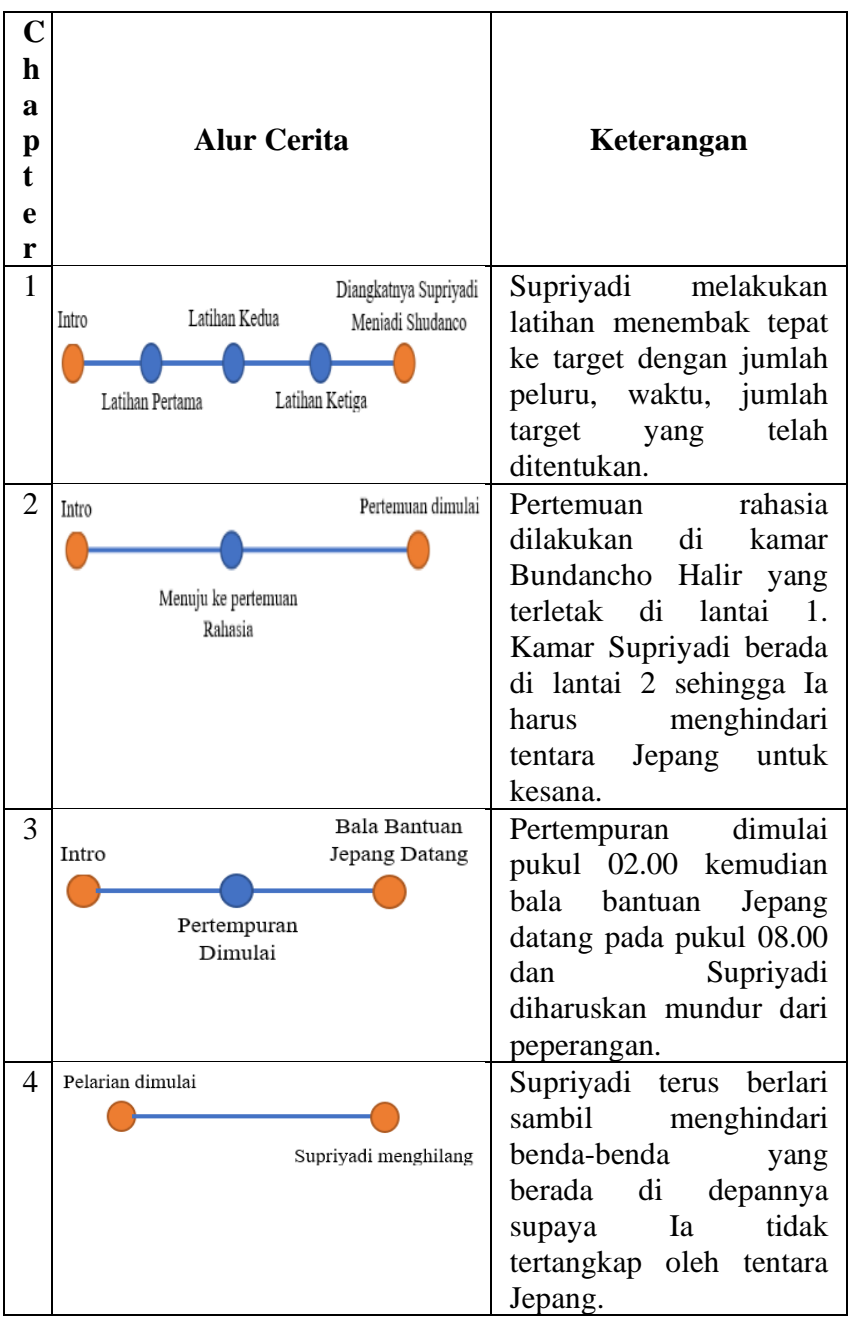

Permainan terdiri dari empat bagian / chapter. Setiap chapter memiliki gameplay progression sebagai berikut:

1. Chapter 1

Player harus menembak target tepat sasaran dimana latihan pertama akan diberikan 5 target dengan peluru yang disediakan sebanyak 8. Latihan kedua pemain diminta untuk menembak target yang bergerak maju mundur yang bermunculan secara acak dalam waktu 1 menit. Pada latihan ini terdapat 5 target dan peluru yang disediakan sebanyak 7. Latihan ketiga player harus menembak 5 target yang bermunculan secara acak dengan 6 peluru. Jika waktu dan peluru habis tetapi target masih ada maka player dianggap gugur tetapi jika player berhasil menembak semua target dan waktu masih tersisa player dianggap lolos ke tahap berikutnya

\section{Chapter 2}

Pada chapter ini, player harus menuju ke sebuah tempat pertemuan rahasia. Dalam perjalanan menuju tempat pertemuan, player harus menghindari tentara Jepang tanpa diketahui. Sesampainya di tempat pertemuan rahasia, rencana perlawanan terhadap Jepang dimulai.

\section{Chapter 3}

Pada chapter ini, sesuai dengan yang telah direncanakan untuk melakukan perlawanan terhadap tentara Jepang. Ketika di dalam asrama player harus membunuh 5(lima) tentara Jepang tanpa diketahui. Kemudian player harus membunuh sebanyak 15(lima belas) tentara Jepang yang berada di luar asrama. Player harus menyelesaikannya sebelum jam 08:00 dikarenakan adanya bala bantuan tentara Jepang yang datang.

\section{Chapter 4}

Player harus menghindari rintangan-rintangan selagi karakter berlari sehingga menuju ke hutan agar bisa lolos dari kejaran tentara Jepang. Pada chapter ini player harus menghindari kejaran tentara Jepang sampai ke titik point yang telah ditentukan, jika player berhasil sampai ke titik point maka player dianggap berhasil, sebaliknya jika player tidak sampai ke titik point maka player dianggap gugur.

Tabel II menjelaskan struktur misi atau tantangan yang akan dilalui atau dihadapi oleh player dari chapter 1 sampai chapter 4 .

TABEL II

STRUKTUR MISI

\begin{tabular}{|c|c|c|c|}
\hline \multicolumn{2}{|c|}{ Chapter } & Tantangan & Keterangan \\
\hline \multirow{3}{*}{1} & $\begin{array}{l}\text { Stage } \\
1\end{array}$ & $\begin{array}{l}\text { Waktu tantangan } 60 \\
\text { detik. Player } \\
\text { diberikan } 10 \text { peluru. } \\
\text { Dalam waktu yang } \\
\text { diberikan player } \\
\text { diharuskan } \\
\text { menembak } 5 \text { target } \\
\text { yang disediakan. }\end{array}$ & $\begin{array}{l}\text { Target muncul secara } \\
\text { random dan setelah } \\
\text { menembak tidak bisa } \\
\text { menembak lagi hingga } 3 \\
\text { detik terlewati. }\end{array}$ \\
\hline & $\begin{array}{l}\text { Stage } \\
2\end{array}$ & $\begin{array}{l}\text { Waktu tantangan } 50 \\
\text { detik. Player } \\
\text { diberikan } 7 \text { peluru. } \\
\text { Dalam waktu yang } \\
\text { diberikan player } \\
\text { diharuskan } \\
\text { menembak } 5 \text { target } \\
\text { yang disediakan. }\end{array}$ & $\begin{array}{l}\text { Target muncul secara } \\
\text { random dengan bergerak } \\
\text { maju mundur dan setelah } \\
\text { menembak tidak bisa } \\
\text { menembak lagi hingga } 3 \\
\text { detik terlewati. }\end{array}$ \\
\hline & $\begin{array}{l}\text { Stage } \\
3\end{array}$ & $\begin{array}{l}\text { Waktu tantangan } 40 \\
\text { detik. Player } \\
\text { diberikan } 6 \text { peluru. } \\
\text { Dalam waktu yang } \\
\text { diberikan player } \\
\text { diharuskan } \\
\text { menembak } 5 \text { target } \\
\text { yang disediakan. }\end{array}$ & $\begin{array}{l}\text { Target muncul secara } \\
\text { random dengan bergerak } \\
\text { kiri-kanan terus menerus } \\
\text { dan setelah menembak } \\
\text { tidak bisa menembak lagi } \\
\text { hingga } 3 \text { detik terlewati. }\end{array}$ \\
\hline 2 & & $\begin{array}{l}\text { Dari kamar } \\
\text { Supriyadi menuju ke } \\
\text { kamar Bundancho } \\
\text { Halir di lantai } 1 \\
\text { asrama. }\end{array}$ & $\begin{array}{l}\text { Dalam perjalanan untuk } \\
\text { ke kamar Bundancho halir } \\
\text { terdapat banyak penjaga } \\
\text { yang berkeliling. Pemain } \\
\text { tidak boleh tertangkap } \\
\text { oleh penjaga. }\end{array}$ \\
\hline
\end{tabular}




\begin{tabular}{|l|l|l|}
\hline Chapter & \multicolumn{1}{|c|}{ Tantangan } & \multicolumn{1}{c|}{ Keterangan } \\
\hline \multirow{4}{*}{3} & $\begin{array}{l}\text { Pemain diharuskan } \\
\text { membunuh 20 } \\
\text { tentara Jepang } \\
\text { dengan waktu yang } \\
\text { disediakan yaitu dari } \\
\text { pukul 02.00 hingga } \\
08.00 .\end{array}$ & $\begin{array}{l}\text { Dengan skala } \\
\text { perbandingan waktu 1 } \\
\text { jam sama dengan 1 menit, } \\
\text { maka pemain hanya } \\
\text { memiliki waktu 6 menit } \\
\text { untuk membunuh 20 } \\
\text { tentara Jepang yang } \\
\text { berada pada asrama,pos- } \\
\text { pos, dan rumah. }\end{array}$ \\
\hline \multirow{4}{*}{4} & $\begin{array}{l}\text { Berhasil lolos dari } \\
\text { pengejaran Tentara } \\
\text { Jepang dengan } \\
\text { menuju ke hutan } \\
\text { lebat. }\end{array}$ & $\begin{array}{l}\text { Pemain yang } \\
\text { memerankan Supriyadi } \\
\text { yang sedang berlari } \\
\text { dengan berbagai } \\
\text { rintangan yang harus } \\
\text { dihindari dengan } \\
\text { menggerakan karakter ke } \\
\text { bagian kiri atau bagian } \\
\text { kanan. }\end{array}$ \\
\hline & & \\
& &
\end{tabular}

Tujuan akhir dari permainan ini adalah menyelesaikan seluruh petualangan Shodanco Supriyadi. Dimulai dari chapter 1 harus menyelesaikan setiap stage, dengan cara menembak target dengan tepat. Lalu Chapter 2, harus menuju ke tempat pertemuan rahasia tanpa diketahui oleh penjaga atau tentara Jepang. Chapter 3 harus menembak 20 tentara Jepang sebelum jam 08:00 dan chapter terakhir yaitu chapter 4 harus melarikan diri dari kejaran tentara Jepang hingga ke titik point tertentu.

Objek utama dalam permainan terdiri dari senapan M1 Garrand sebagai senjata dan target papan sebagai target penembakan. Keterangan objek dijelaskan pada Tabel III.

TABEL III

OBJEK DALAM GAME

\begin{tabular}{|c|c|c|c|c|}
\hline No & Gambar & \multicolumn{2}{|c|}{ Nama dan Peran } & Keterangan \\
\hline \multirow[t]{2}{*}{1} & \multirow{2}{*}{ 平 } & Nama & M1 Garrand & \multirow{2}{*}{$\begin{array}{l}\text { Senjata yang } \\
\text { digunakan oleh } \\
\text { player. }\end{array}$} \\
\hline & & Peran & Senjata & \\
\hline \multirow{2}{*}{2} & & Nama & $\begin{array}{l}\text { Target } \\
\text { Papan }\end{array}$ & \multirow{2}{*}{$\begin{array}{l}\text { Dijadikan sebagai } \\
\text { target } \\
\text { penembakan yang } \\
\text { ada di Chapter } 1 .\end{array}$} \\
\hline & & Peran & $\begin{array}{l}\text { Target } \\
\text { penembakan }\end{array}$ & \\
\hline \multirow{2}{*}{3} & & Nama & $\begin{array}{l}\text { Tentara } \\
\text { Jepang }\end{array}$ & \multirow{2}{*}{$\begin{array}{l}\text { Tentara ini } \\
\text { terdapat pada } \\
\text { Chapter } 3 \text { dimana } \\
\text { player bisa } \\
\text { ditembak dan } \\
\text { tentara ini bisa } \\
\text { terkena tembakan } \\
\text { juga. }\end{array}$} \\
\hline & & Peran & $\begin{array}{l}\text { Menembak } \\
\text { player }\end{array}$ & \\
\hline
\end{tabular}

Dalam permainan ini pemain dapat melakukan aksi dan interaksi pada objek seperti menembak, pause, dan 15ombola arah dengan keterangan yang dijelaskan pada Tabel IV.
TABEL IV

TOMBOL AKSI DAN INTERAKSI OBJEK

\begin{tabular}{|l|c|l|}
\hline No & Gambar & \multicolumn{1}{|c|}{ Fungsi } \\
\hline 1. & & $\begin{array}{l}\text { Fungsi 15ombola tau button } \\
\text { bergambar pistol adalah untuk } \\
\text { menembak. }\end{array}$ \\
\hline 2. & $\begin{array}{l}\text { Tombol ini berfungsi untuk } \\
\text { menghentikan (pause) game sejenak. }\end{array}$ \\
\hline 3. & $\begin{array}{l}\text { Ini adalah sebuah joystick yang } \\
\text { berfungsi untuk menggerakkan } \\
\text { karakter atau mengarahkan karakter ke } \\
\text { bawah, atas, kiri, dan kanan. }\end{array}$ \\
\hline 4. & 500 & $\begin{array}{l}\text { Berfungsi untuk berpindah sisi ke } \\
\text { sebelah kiri. }\end{array}$ \\
\hline 5. & $0 \begin{array}{l}\text { Berfungsi untuk berpindah sisi ke } \\
\text { sebelah kanan. }\end{array}$ \\
\hline
\end{tabular}

Gambar 4 merupakan screenflow yang menjelaskan secara garis besar atau menciptakan imajinasi ke player ke mana akan dibawa dalam sebuah layar atau tampilan. Pada menu utama terdapat tombol mulai dan tombol tentang kami. Ketika menekan tombol tentang kami akan ditampilkan profil pembuat permainan. Jika ingin memulai permainan dapat menekan tombol mulai, setelah menekan tombol tersebut akan ditampilkan background story permainan, setelah background story selesai ditampilkan maka akan masuk ke chapter 1, chapter 2, chapter 3, dan chapter 4 . Pada masing-masing chapter sebelum masuk akan terdapat loading scene, dan ketika telah selesai menyelesaikan chapter 4 maka akan menampilkan ending 1 scene. Kemudian akan menampilkan proklamasi Scene yaitu yang berupa video. Setelah itu akan ditampilkan ending 2 scene dan selanjutnya terimakasih scene.

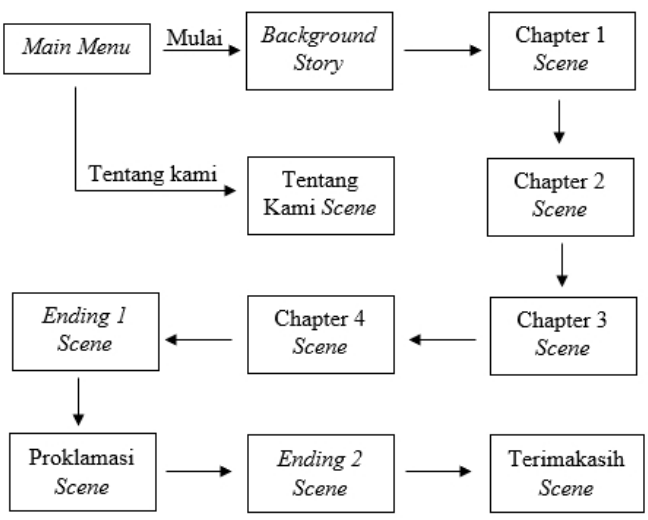

Gambar 4. Screenflow

Terdapat beberapa karakter utama dan karakter pembantu pada permainan ini yang diperlihatkan pada Tabel V. Karakter utama adalah Supriyadi [16] dan Leon yang kemudian akan berperan sebagai Supriyadi. 
TABEL V

KARAKTER DALAM GAME

\begin{tabular}{|c|c|c|}
\hline No & $\begin{array}{c}\text { Nama } \\
\text { Karakter }\end{array}$ & Keterangan \\
\hline 1. & $\begin{array}{l}\text { Supriyadi } \\
\text { Karakter } \\
\text { Utama }\end{array}$ & $\begin{array}{l}\text { Supriyadi lahir di Trenggalek, Jawa } \\
\text { Timur, pada tanggal 13 April } 1923 . \\
\text { Sebenarnya nama aslinya adalah } \\
\text { Priambodo. } \\
\text { Oleh karena sering sakit-sakitan, akhirnya } \\
\text { orang tuanya mengganti namanya } \\
\text { menjadi Supriyadi. Setelah tamat ELS } \\
\text { (setingkat Sekolah Dasar), Supriyadi } \\
\text { melanjutkan pendidikan MULO } \\
\text { (setingkat Sekolah Menengah Pertama), } \\
\text { kemudian memasuki Sekolah Pamong } \\
\text { Praja di Magelang [16] }\end{array}$ \\
\hline 2. & $\begin{array}{l}\text { Leon } \\
\text { Karakter } \\
\text { Utama }\end{array}$ & $\begin{array}{l}\text { Leon lahir di kota Blitar pada tanggal } 20 \\
\text { Desember 2015. Ia diberi nama Leon } \\
\text { dikarenakan orang tuanya berharap } \\
\text { bahwa ia akan menjadi seorang } \\
\text { pemberani dan selalu fokus dengan } \\
\text { tujuannya. Sejak kecil Leon sangat dekat } \\
\text { dengan kakeknya dikarenakan kakeknya } \\
\text { sering menceritakan pengalaman } \\
\text { mudanya pada semasa ke pendudukan } \\
\text { Jepang di Indonesia sehingga kini Leon } \\
\text { sangat terobsesi dengan hal tersebut. } \\
\text { Leon dikenal sebagai pribadi yang sangat } \\
\text { menarik dikarenakan ia memiliki sifat } \\
\text { yang periang, dan ketika ia melakukan } \\
\text { sesuatu maka ia lakukan dengan sungguh- } \\
\text { sungguh. Ia sangat ingin sekali untuk } \\
\text { menjadi seorang guru yang mengajar } \\
\text { sejarah, sehingga saat ini yaitu ketika ia } \\
\text { berumur 18 tahun ia pun masuk ke } \\
\text { jenjang lebih tinggi lagi dalam } \\
\text { pendidikan yaitu tingkat perkuliahan. }\end{array}$ \\
\hline 3. & $\begin{array}{l}\text { Karakter } \\
\text { Pembantu }\end{array}$ & $\begin{array}{l}\text { Berada dalam dialog awal permainan } \\
\text { yang di mana ketika itu Leon pergi } \\
\text { membeli bahan. }\end{array}$ \\
\hline 4. & $\begin{array}{l}\text { Mr. } \\
\text { Misterius } \\
\text { Karakter } \\
\text { Pembantu }\end{array}$ & $\begin{array}{l}\text { Peran karakter ini yaitu memberikan } \\
\text { sebuah konsol permainan kepada Leon } \\
\text { sehingga si Leon masuk ke dalam sebuah } \\
\text { game. }\end{array}$ \\
\hline 5. & $\begin{array}{l}\text { Instruktur } \\
\text { Dai Nippon } \\
\text { Karakter } \\
\text { Pembantu }\end{array}$ & $\begin{array}{l}\text { Karakter ini berperan dalam memberikan } \\
\text { misi kepada player yang ketika itu } \\
\text { karakter yang dimainkan adalah } \\
\text { Supriyadi. }\end{array}$ \\
\hline 6. & $\begin{array}{l}\text { Black } \\
\text { Avatar } \\
\text { Karakter } \\
\text { Pembantu }\end{array}$ & $\begin{array}{l}\text { Perannya adalah sebagai seseorang yang } \\
\text { bernama Muradi, Sunanto, Lainnya, } \\
\text { Suparjono. }\end{array}$ \\
\hline
\end{tabular}

Latar belakang dimulai ketika Leon mendengar kisah sang kakek yang membuat Ia akhirnya memutuskan mengambil studi jurusan sejarah di luar kota. Tabel VI menjelaskan cerita latar belakang permainan. Di luar kota Leon membeli console dari seorang misterius yang mengakibatkan Ia terperangkap dalam sebuah game atau permainan.

TABEL VI

DESKRIPSI STORY AWAL

\begin{tabular}{|c|c|}
\hline Story & Deskripsi \\
\hline $\begin{array}{l}\text { Kisah Sang } \\
\text { Kakek }\end{array}$ & $\begin{array}{l}\text { Leon ketika itu sedang berkunjung ke rumah } \\
\text { kakeknya untuk memperingati hari ulang tahun } \\
\text { yang ke }-100 \text {. Leon saat itu berumur } 7 \text { tahun, } \\
\text { dan ia ingin mendengar suatu cerita dari sang } \\
\text { kakek. Kemudian sang kakek pun menceritakan } \\
\text { tentang kehidupannya yang menderita pada } \\
\text { masa ke pendudukan Jepang. Leon pun tertarik } \\
\text { mendengar cerita dari kakeknya sehingga } \\
\text { bertanya-tanya kenapa Jepang menjajah negara } \\
\text { Indonesia. Sang kakek tidak bisa menjawab } \\
\text { banyak hal yang ditanyakan oleh Leon, oleh } \\
\text { sebab itu ketika Leon sekolah ia banyak } \\
\text { membaca buku tentang sejarah ke pendudukan } \\
\text { Jepang di Indonesia. }\end{array}$ \\
\hline $\begin{array}{l}\text { Penjual } \\
\text { Misterius }\end{array}$ & $\begin{array}{l}\text { Ketika Leon berumur } 18 \text { tahun ia mengambil } \\
\text { studi jurusan sejarah di luar kota. Suatu ketika ia } \\
\text { kehabisan stok makanan sehingga ia pergi } \\
\text { membelinya, pada saat di perjalanan pulang ia } \\
\text { melewati sebuah gang kecil dan bertemu } \\
\text { seseorang yang misterius. Orang itu pun } \\
\text { memanggil Leon dan menawarkan suatu } \\
\text { console permainan tentang sejarah dari seorang } \\
\text { Shodanco Supriyadi, karena penasaran ia } \\
\text { membelinya tanpa berpikir panjang. }\end{array}$ \\
\hline $\begin{array}{l}\text { Masuknya } \\
\text { Leon ke } \\
\text { dalam game }\end{array}$ & $\begin{array}{l}\text { Sesampai dirumah Leon langsung mencoba } \\
\text { game tersebut. Seketika game tersebut dimulai, } \\
\text { ia mulai kehilangan kesadaran dan samar-samar } \\
\text { terdengar suatu suara yang berbunyi "kamu } \\
\text { tidak bisa keluar dari game ini sebelum kamu } \\
\text { menyelesaikannya". Ketika bangun Leon } \\
\text { terkejut karena ia menyadari ini bukan } \\
\text { rumahnya. Leon berpikir keras dan mendapati } \\
\text { bahwa ia masuk ke dalam permainan tersebut. }\end{array}$ \\
\hline
\end{tabular}

Pada chapter 1 terdapat beberapa misi yang harus diselesaikan. Tabel VII merupakan storyline chapter 1. Saat memulai game terdapat intro, kemudian player harus menyelesaikan misi latihan pertama, latihan kedua, latihan ketiga, hingga mendapatkan gelar Shodanco.

TABEL VII

STORYLINE CHAPTER 1

\begin{tabular}{|l|l|}
\hline Story & Deskripsi \\
\hline \multirow{3}{*}{ Intro } & $\begin{array}{l}\text { Ketika tidak sadarkan diri Leon bertemu } \\
\text { dengan suatu sosok yang sangat terang hingga }\end{array}$ \\
& $\begin{array}{l}\text { Ia tidak dapat melihatnya. Sosok tersebut } \\
\text { menjelaskan kepada Leon bahwa Ia akan } \\
\text { memerankan sebagai orang yang Supriyadi }\end{array}$ \\
\hline
\end{tabular}




\begin{tabular}{|c|c|}
\hline Story & Deskripsi \\
\hline & $\begin{array}{l}\text { nantinya. Sosok tersebut juga menjelaskan } \\
\text { bahwa Pada bulan Oktober 1943, Jepang } \\
\text { membentuk Tentara Pembela Tanah Air } \\
\text { (PETA). Setelah itu Leon seketika masuk ke } \\
\text { dalam game Ia menyadari bahwa ini bukanlah } \\
\text { tubuhnya dan nampaknya kini Ia telah } \\
\text { menjadi seseorang yang bernama Supriyadi. }\end{array}$ \\
\hline $\begin{array}{l}\text { Latihan } \\
\text { Pertama }\end{array}$ & $\begin{array}{l}\text { Supriyadi diterima di PETA, Ia disuruh } \\
\text { melakukan latihan tembak menembak oleh } \\
\text { instruktur di lapangan yaitu tentara Dai } \\
\text { Nippon. Instruktur itu berkata bahwa latihan } \\
\text { pertamanya yaitu adalah dengan waktu } 1 \\
\text { menit dengan menembak target yang } \\
\text { munculnya acak tetapi tidak bergerak dengan } \\
\text { syarat harus menembak } 5 \text { target dengan hanya } \\
\text { menggunakan } 10 \text { peluru yang diberikan. } \\
\text { Supriyadi pun mencoba latihan pertamanya } \\
\text { dan Ia berhasil melakukannya dengan sisa } \\
\text { waktu } 8 \text { detik dan penggunaan peluru hanya } 7 \\
\text { dari } 10 \text { peluru yang diberikan. }\end{array}$ \\
\hline $\begin{array}{l}\text { Latihan } \\
\text { Kedua }\end{array}$ & $\begin{array}{l}\text { Instruktur kemudian memberi menu latihan } \\
\text { yang kedua kepada Supriyadi yaitu dengan } \\
\text { hanya } 7 \text { peluru Ia harus menembak } 5 \text { target } \\
\text { yang sedang bergerak maju mundur yang juga } \\
\text { munculnya secara acak dengan waktu } 50 \\
\text { detik saja. Supriyadi pun cukup terkejut akan } \\
\text { hal itu tetapi Ia yakin bahwa bisa } \\
\text { melakukannya karena "bila hal ini saja tidak } \\
\text { bisa maka aku tidak pantas untuk menjadi } \\
\text { anggota PETA" pikirnya. Tibalah giliran } \\
\text { Supriyadi dan Ia pun mencobanya ternyata } \\
\text { percobaan pertama Ia tidak berhasil } \\
\text { melakukannya dikarenakan Ia melebihi waktu } \\
\text { dalam menyelesaikannya. Supriyadi pun } \\
\text { melakukan percobaan kedua dan akhirnya Ia } \\
\text { berhasil dengan menggunakan seluruh peluru } \\
\text { yang diberikan dengan sisa waktu } 5 \text { detik. }\end{array}$ \\
\hline $\begin{array}{l}\text { Latihan } \\
\text { Ketiga }\end{array}$ & $\begin{array}{l}\text { Instruktur lanjut memberikan menu latihan } \\
\text { lagi kepada anggota-anggota PETA termasuk } \\
\text { Supriyadi. Menu latihannya yaitu hanya } \\
\text { diberikan } 6 \text { peluru dan harus menembaki } 5 \\
\text { target yang bergerak ke segala arah dan } \\
\text { munculnya juga acak dengan waktu } 40 \text { detik. } \\
\text { Supriyadi terkaget bahwa semakin lama } \\
\text { latihan yang diberikan semakin sulit tetapi Ia } \\
\text { tetap semangat dalam menghadapinya. } \\
\text { Kemudian tibalah gilirannya untuk } \\
\text { melakukan latihannya tetapi ternyata Ia gagal } \\
\text { dalam menyelesaikannya. Percobaan } \\
\text { pertamanya gagal dikarenakan habisnya } \\
\text { peluru dan masih tersisa } 1 \text { target lagi yang } \\
\text { harus ia jatuhkan. Kemudian Ia mencoba } \\
\text { untuk kedua kalinya tetapi kali ini Ia gagal } \\
\text { kembali dikarenakan selesai dengan melebihi } \\
\text { waktu yang telah ditentukan. Supriyadi tetap } \\
\text { semangat dan terus mencoba sehingga pada } \\
\text { saat yang keempat kalinya Ia berhasil } \\
\text { menyelesaikannya dengan sisa waktu } 2 \text { detik } \\
\text { saja. }\end{array}$ \\
\hline $\begin{array}{l}\text { Diangkatnya } \\
\text { Supriyadi }\end{array}$ & $\begin{array}{l}\text { Setelah selesai latihan, Supriyadi dipanggil } \\
\text { oleh instruktur. Instruktur itu berkata bahwa }\end{array}$ \\
\hline
\end{tabular}

\begin{tabular}{|l|l|}
\hline Story & Deskripsi \\
\hline Menjadi & $\begin{array}{l}\text { Supriyadi layak untuk menjadi salah satu } \\
\text { Shudanco } \\
\text { Shodanco (Komandan Peleton) dikarenakan } \\
\text { bagusnya Ia dalam hal menembak dan } \\
\text { cepatnya dalam menyelesaikannya. Ia tidak } \\
\text { mengerti akan hal itu, kemudian Ia } \\
\text { menanyakan ada pangkat apa saja dalam } \\
\text { PETA. Instruktur pun menjelaskan bahwa } \\
\text { Keanggotaan PETA dibedakan menjadi lima } \\
\text { pangkat, yaitu: } \\
\text { 1. Daidanco (Komandan Batalyon) } \\
\text { Dipilih dari tokoh-tokoh masyarakat } \\
\text { seperti pemimpin agama, dan lain-lain. } \\
\text { 2. Cudanco (Komandan Kompi) } \\
\text { Dipilih dari mereka yang bekerja, tetapi } \\
\text { belum memiliki jabatan yang tinggi } \\
\text { seperti guru dan lain-lain. } \\
\text { 3. Shodanco (Komandan Peleton) } \\
\text { Dipilih dari para pelajar SMP dan SMA. } \\
\text { 4. Budhanco (Komandan Regu) } \\
\text { 5. Giyuhei (Prajurit Sukarela) } \\
\text { Dipilih dari para pelajar sekolah dasar. } \\
\text { Setelah mendengar hal itu Ia sangat senang } \\
\text { bisa menjadi salah satu komandan. }\end{array}$ \\
\hline
\end{tabular}

Pada chapter 2 terdapat misi menuju ke tempat pertemuan rahasia. Di pertemuan tersebut telah terdapat 3 orang yaitu Muradi, Suparjono, dan Sunanto [17]. Tabel VIII menjelaskan storyline chapter kedua. Saat memulai game pada chapter 2, terdapat intro dari chapter tersebut, kemudian player harus menuju ke tempat pertemuan rahasia, dan pertemuan dimulai.

\section{TABEL VIII}

\section{STORYLINE CHAPTER 2}

\begin{tabular}{|c|l|}
\hline Story & Deskripsi \\
\hline \multirow{5}{*}{ Intro } & $\begin{array}{l}\text { Supriyadi ketika menjadi anggota PETA Ia } \\
\text { seringkali dipukuli oleh tentara Jepang dan } \\
\text { begitu juga dengan teman-temannya. Orang desa } \\
\text { juga kalau lewat depan asrama harus berhenti } \\
\text { dan membungkuk. Kalau sampai ada yang lewat } \\
\text { dan lupa membungkuk, juga langsung dipukuli. } \\
\text { Padahal rakyat desa kan tidak mengerti, pikir } \\
\text { Supriyadi. Ia melihat hal itu dari dalam asrama } \\
\text { sehingga Ia pun tidak tahan dan akhirnya Ia } \\
\text { dendam dengan Jepang. Hingga suatu hari Ia } \\
\text { mulai menghasut beberapa orang dan kemudian } \\
\text { mengajak untuk mengadakan pertemuan rahasia. }\end{array}$ \\
\hline $\begin{array}{l}\text { Pertemuan rahasia akan dilakukan di malam hari } \\
\text { di kamar Bundancho (komandan regu) Halir. } \\
\text { Malam pun tiba, Supriyadi berada di kamar } \\
\text { Menuju ke } \\
\text { pertemuan } \\
\text { Rahasia } \\
\text { pertemuan berada di lantai 1 sehingga Ia harus } \\
\text { mengendap-ngendap agar pengawas tidak } \\
\text { mengetahuinya. Ketika Ia mengendap-endap } \\
\text { ternyata ada pengawas yang selalu mengawasi } \\
\text { sekelilingnya dengan ditemani oleh musik dari } \\
\text { radio. Ia pun bersabar dan menunggu waktu } \\
\text { yang tepat untuk melewatinya sehingga tidak } \\
\text { terlihat oleh tentara-tentara Jepang. Ketika di }\end{array}$ \\
\hline
\end{tabular}




\begin{tabular}{|c|c|}
\hline Story & Deskripsi \\
\hline & $\begin{array}{l}\text { lantai } 1 \text { Ia melihat bahwa kamar Bundancho } \\
\text { Halir terdapat } 1 \text { tentara Jepang yang sedang } \\
\text { mengawasi, sehingga Ia dengan sangat berhati- } \\
\text { hati dan pelan-pelan menuju ke ruangan tersebut } \\
\text { ketika tentaranya tidak melihat. }\end{array}$ \\
\hline $\begin{array}{c}\text { Pertemuan } \\
\text { dimulai }\end{array}$ & 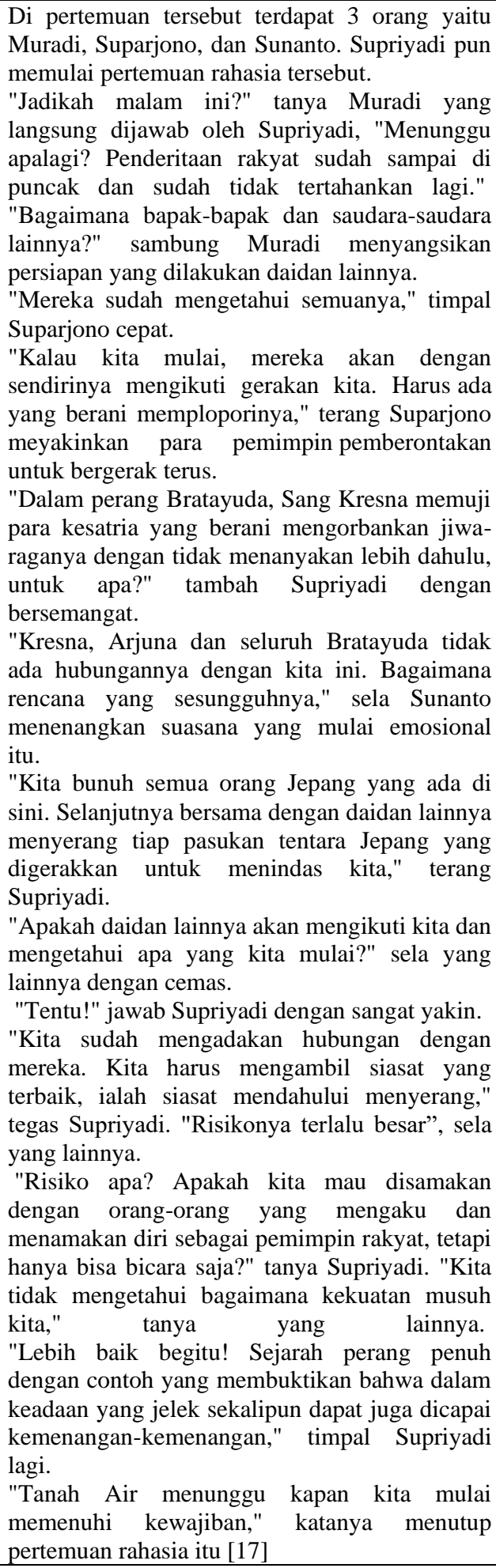 \\
\hline
\end{tabular}

Pada chapter 3 terdapat misi menembaki tentara Jepang. Tabel IX menjelaskan storyline chapter ketiga. Saat memulai chapter ketiga terdapat intro, kemudian player harus membunuh 20 tentara Jepang sebelum bala bantuan Jepang datang.

TABEL IX

STORYLINE CHAPTER 3

\begin{tabular}{|c|c|}
\hline Story & Deskripsi \\
\hline Intro & $\begin{array}{l}\text { Waktu menunjukkan pukul } 02.00 \text { pada tanggal } \\
15 \text { Februari } 1945 \text { dimana perlawanan anggota } \\
\text { PETA di Blitar terhadap tentara Jepang } \\
\text { dimulai. Supriyadi sebagai pemimpin dari } \\
\text { serangan Ia memulai penyerangan tersebut pada } \\
\text { jam segini dikarenakan ini adalah waktu yang } \\
\text { tepat karena tentara jepang banyak yang telah } \\
\text { tidur. }\end{array}$ \\
\hline $\begin{array}{l}\text { Pertempur } \\
\text { an dimulai }\end{array}$ & $\begin{array}{l}\text { Ia mulai dengan menembaki para tentara } \\
\text { Jepang yang ada di asrama. Di asrama terdapat } \\
5 \text { tentara Jepang sehingga Ia dan teman- } \\
\text { temannya pun membunuhnya. Kemudian Ia dan } \\
\text { yang lainnya mulai mendatangi pos-pos dan } \\
\text { rumah-rumah. Di pos Ia dengan yang lainnya } \\
\text { kembali membunuh } 1 \text { orang, begitupun juga } \\
\text { dengan pos berikutnya, dan tentara Jepang yang } \\
\text { tinggal di rumah pun Ia dan temannya juga } \\
\text { menghabisinya. Sehingga ada sekitar } 20 \text { tentara } \\
\text { Jepang yang telah meninggal. }\end{array}$ \\
\hline $\begin{array}{c}\text { Bala } \\
\text { Bantuan } \\
\text { Jepang } \\
\text { Datang }\end{array}$ & $\begin{array}{l}\text { Tetapi tentara Jepang baik dalam } \\
\text { berkomunikasi sehingga pada pukul } 08.00 \text { bala } \\
\text { bantuan tentara Jepang datang. Supriyadi dan } \\
\text { teman-temannya tetap melawannya sehingga } \\
\text { mereka pun akhirnya kehabisan peluru [18]. }\end{array}$ \\
\hline
\end{tabular}

Pada chapter 4 terdapat misi harus melarikan diri dari musuh. Tabel X menjelaskan storyline chapter keempat. Saat memulai chapter 4, terdapat player yang langsung harus melarikan diri dari kejaran tentara Jepang.

TABEL X

STORYLINE CHAPTER 4

\begin{tabular}{|c|c|}
\hline Story & Deskripsi \\
\hline $\begin{array}{c}\text { Pelarian } \\
\text { dimulai }\end{array}$ & $\begin{array}{l}\text { Mereka kehabisan peluru, Supriyadi } \\
\text { memerintahkan pasukannya untuk segera } \\
\text { mundur. Akan tetapi teman-temannya banyak } \\
\text { yang tidak berhasil dan akhirnya ditangkap. Ia } \\
\text { terus saja berlari dengan tentara Jepang yang } \\
\text { berada di belakangnya yang ingin } \\
\text { menangkapnya. Ia berlari dengan sekuat } \\
\text { tenaga dan dengan banyak jalan yang tertutup } \\
\text { sehingga Ia mengambil jalan memutar dengan } \\
\text { banyaknya halangan. Ia pun akhirnya bisa } \\
\text { lolos dengan berlari ke arah hutan. }\end{array}$ \\
\hline $\begin{array}{l}\text { Supriyadi } \\
\text { menghilang }\end{array}$ & $\begin{array}{l}\text { Sampai pada tanggal } 14 \text { Agustus } 1945 \text { yaitu } \\
\text { saat Jepang menyerah tanpa syarat ke sekutu } \\
\text { bahkan sampai proklamasi, Supriyadi tidak } \\
\text { ada yang tau kabarnya sama sekali. Sehingga } \\
\text { setelah itu pada tanggal } 9 \text { Agustus } 1975 \\
\text { Presiden Soeharto secara resmi mengangkat }\end{array}$ \\
\hline
\end{tabular}




\begin{tabular}{|l|llr|}
\hline Story & Deskripsi & & \\
\hline & Supriyadi sebagai & Pahlawan Nasional \\
& berdasarkan surat & keterangan No \\
& 063/TK/Tahun 1975. & & \\
& $\begin{array}{l}\text { Perlawanan Supriyadi } \\
\text { memang }\end{array}$ & (elah geTA di Blitar) ini \\
pengaruh sangat besar terutama kepada \\
semangat kemerdekaan rakyat Indonesia \\
terhadap penindasan bangsa asing.
\end{tabular}

Gambar 5 merupakan pengaturan untuk menyesuaikan keinginan player agar permainan dapat berjalan dengan baik. Terdapat 8 fungsi yang dapat diatur yaitu graphic setting, anti-aliasing, vignette, SSR, ambient occlusion, motion blur, bloom, dan color correction. Graphic setting berfungsi untuk mengatur kualitas dari lingkungan sekitar game atau biasa sering disebut environment dalam game. Anti-aliasing berfungsi untuk mengurangi aliasing atau efek patah-patah, anti-aliasing mengubah warna pada pixel di sekitar objek yang terlihat patah-patah menjadi terlihat lebih mulus. Vignette berfungsi untuk membuat efek bayangan di area luar kamera. SSR (screen space refection) menggunakan tampilan scene saat ini untuk memperkirakan pantulan melalui ray tracing. SSR menambahkan efek refleksi yang sangat akurat namun mengaktifkan fitur ini memiliki dampak kepada performa smartphone. Ambient oclussion berfungsi untuk membentuk bayanan pada sudut dan sisi tertentu sebuah objek, ambient occlusion memproses bayangan yang terbentuk tidak hanya dari satu cahaya saja. Motion blur berfungsi menciptakan efek blur yang halus saat menggerakkan kamera. Bloom berfungsi menciptakan kilau dari objek yang terpancar oleh cahaya atau objek yang bercahaya itu sendiri, sedangkan color corecction berfungsi untuk mengatur tingkat keluaran atau masukan warna hitam dan putih, serta menciptakan warna objek yang lebih realistis.

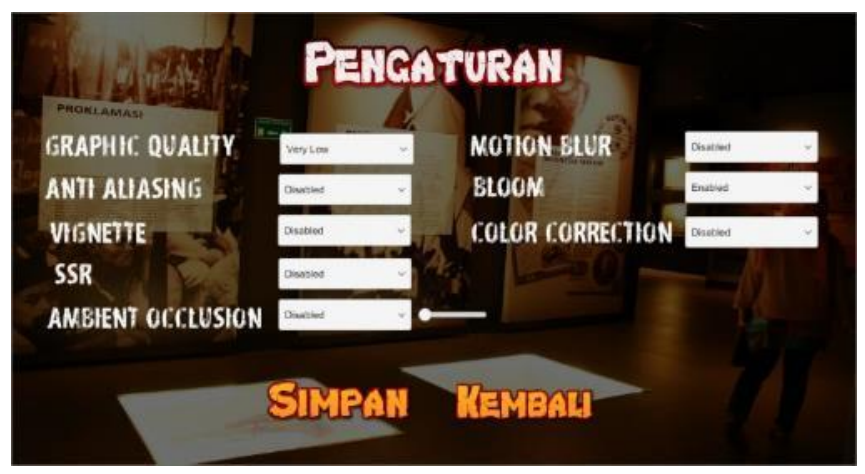

Gambar 5. Pengaturan

\section{Memasukkan Kode Program}

Tahapan ini setelah proses desain yang dibuat sesuai dengan kebutuhan maka dapat dibangun menjadi sebuah game atau sistem dengan memasukkan kode program yang sesuai menggunakan Visual Studio Community 2017 yang menggunakan bahasa $\mathrm{C \#}$.
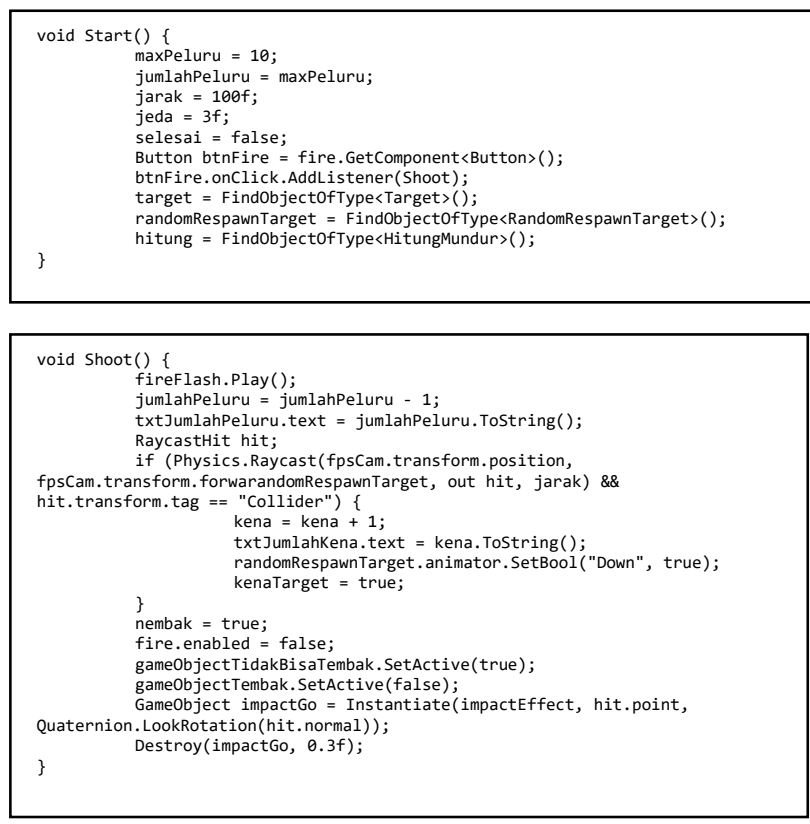

\section{Pengujian}

Tahap pengujian merupakan tahapan untuk melakukan pengujian edugame seperti peta, skenario, dan misi. Pada pengujian ini dilakukan dengan metode unity testing dan system testing untuk menguji fungsi aplikasi apakah telah sesuai dengan hasil yang diharapkan. Pengujian ini juga akan dilakukan dengan menggunakan metode acceptance testing dengan memberikan sample edugame history of Shodanco Supriyadi kepada anak sekolah menengah atas sebanyak 62 orang dan setelah memainkan edugame, maka akan diberikan kuesioner untuk mengetahui seberapa baik edugame yang telah dibuat.

\section{ANALISIS DAN PEMBAHASAN}

\section{A. Tampilan Edugame}

Tampilan menu utama dari game history of shodanco supriyadi dapat dilihat pada Gambar 6. Pada tampilan ini terdapat 3 pilihan yaitu tombol mulai, tentang kami, dan keluar. Tombol mulai berfungsi untuk masuk ke dalam permainan, tombol tentang kami berfungsi untuk menampilkan identitas orang yang membuat game tersebut, dan tombol keluar digunakan untuk keluar dari aplikasi. 


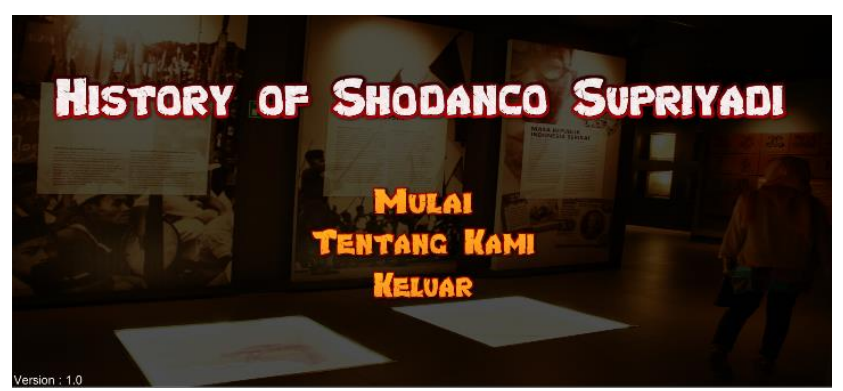

Gambar 6. Tampilan menu utama edugame

Gambar 7 merupakan tampilan controller permainan dari chapter 1 sampai 3 yang terdapat sebuah virtual joystick dan kontrol kamera. Kemudian Gambar 4(c) merupakan tampilan controller permainan pada chapter 4 pengontrolan pergerakan menggunakan tombol panah kanan dan panah kiri yang digunakan untuk bergerak ke arah kanan dan kiri.

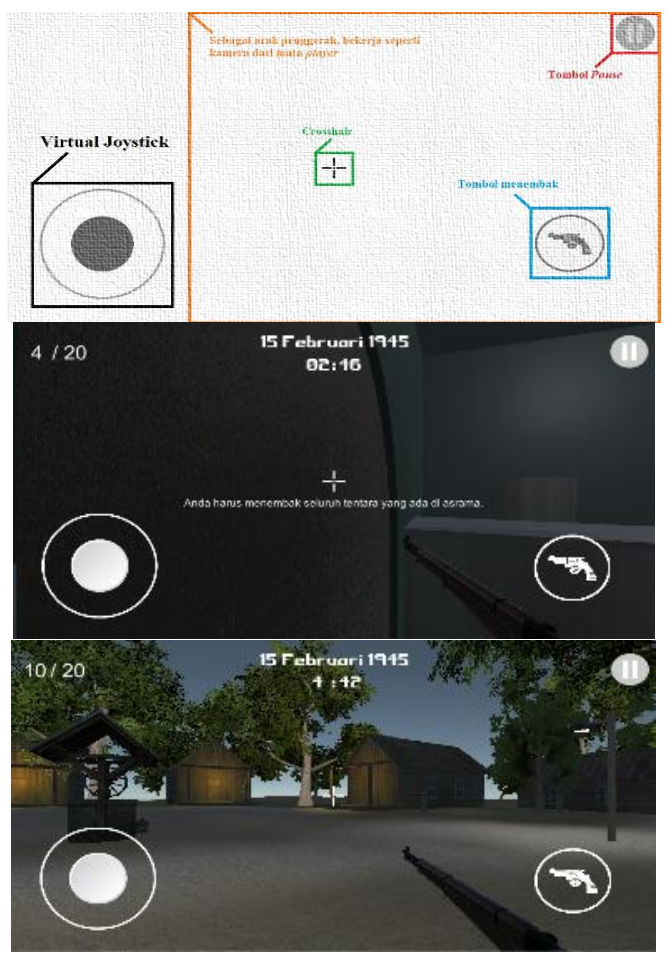

(a) Tampilan controller saat menembak target

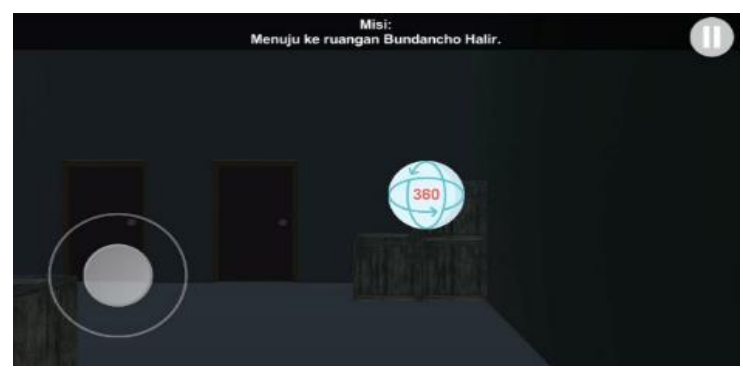

(b) Controller chapter 1 - 3

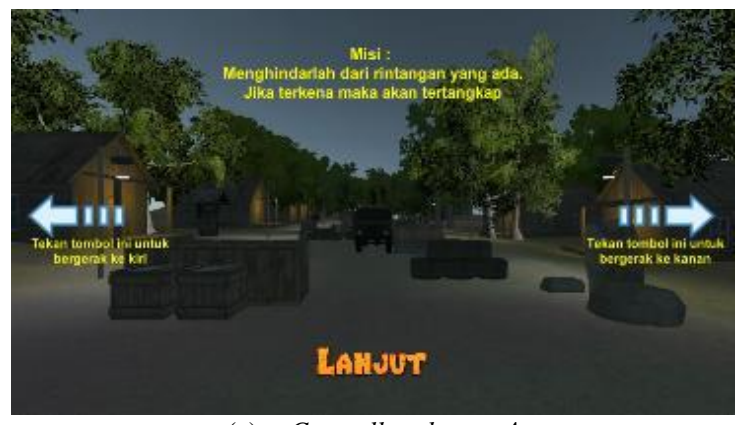

(c) Controller chapter 4

Gambar 7. Tampilan controller

Gambar 8 merupakan tampilan background story yang menjelaskan asal mula karakter Leon dapat memerankan atau menjadi seorang Supriyadi.

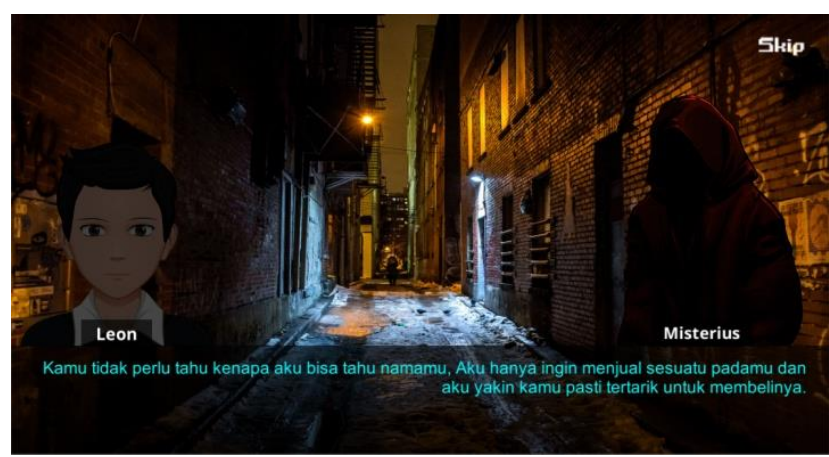

Gambar 8. Tampilan background story

Gambar 9 merupakan tampilan sejarah singkat PETA Blitar, tampilan ini akan selalu tampil sebelum pemain memulai permainan, ini bertujuan agar pemain mengetahui sejarah perlawanan PETA Blitar.

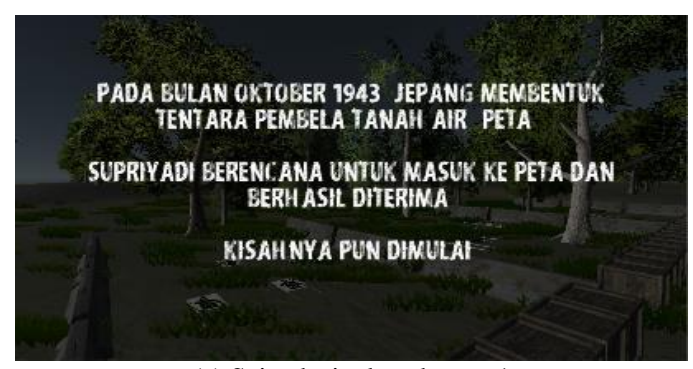

(a) Sejarah singkat chapter 1

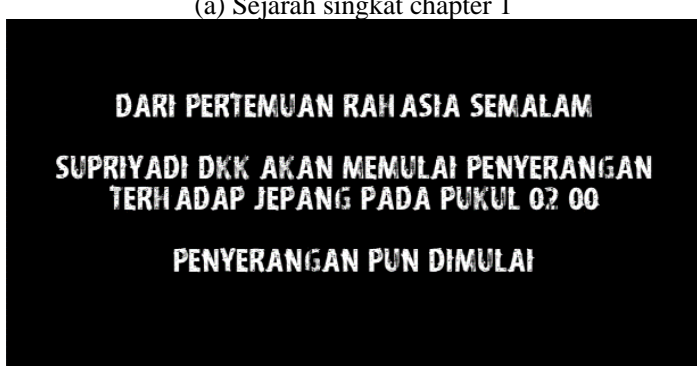

(b) Sejarah singkat chapter 3

Gambar 9. Sejarah PETA Blitar 
Pada Gambar 10 diperlihatkan tampilan panduan untuk membantu pemain dalam memainkan atau memberikan cara untuk menyelesaikan tantangan tersebut, misalkan gameplay dalam menembak papan target, berjalan menuju lokasi yang ditandai cahaya kuning untuk ke misi selanjutnya, dan gameplay dalam menembak 20 tentara musuh.

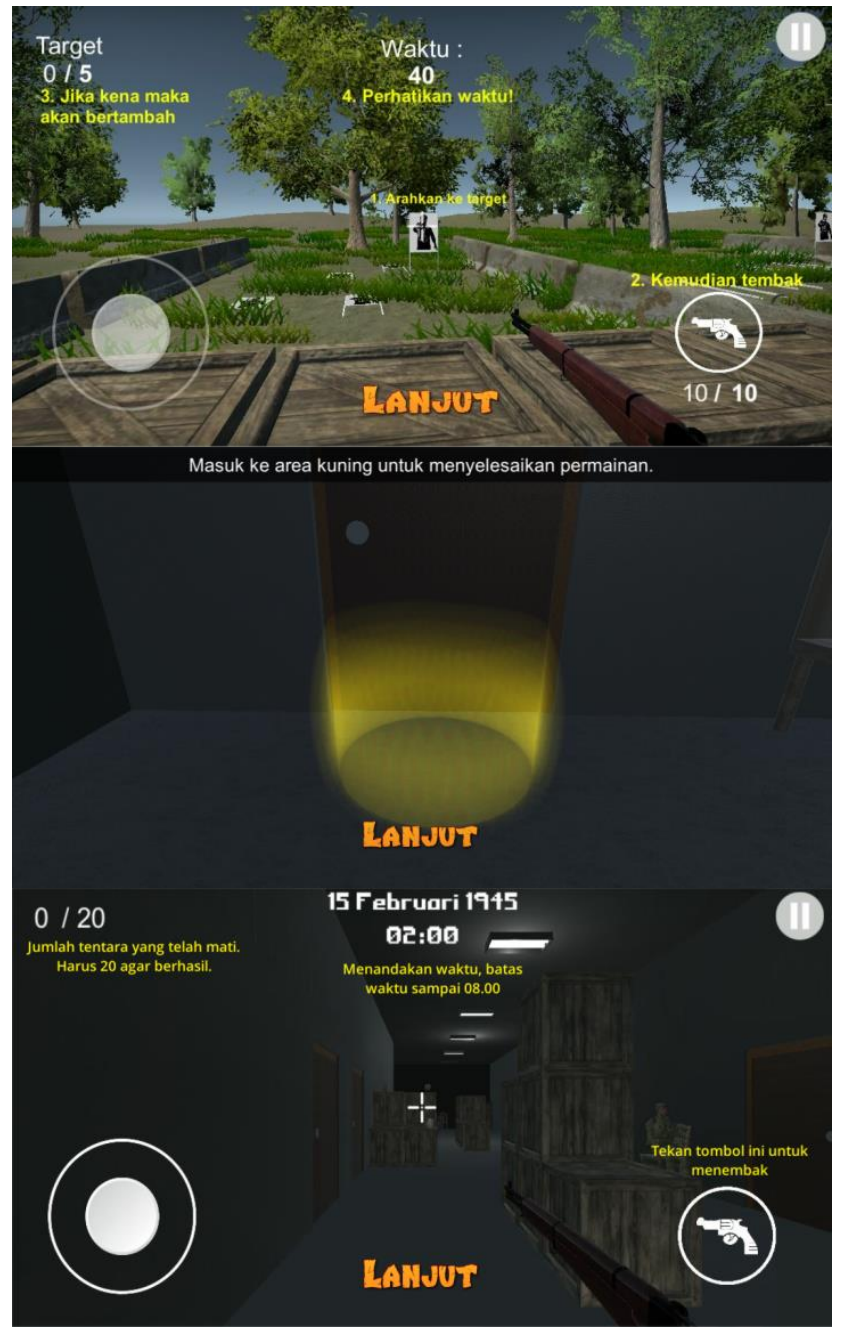

Gambar 10. Tampilan panduan cara bermain

Gambar 11 merupakan contoh percakapan pada saat pemain telah menyelesaikan tahapan chapter 1 dan 2 . Secara otomatis percakapan akan tampil dan untuk melanjutkan ke tahap berikutnya pemain harus menyelesaikan percakapan terlebih dahulu.
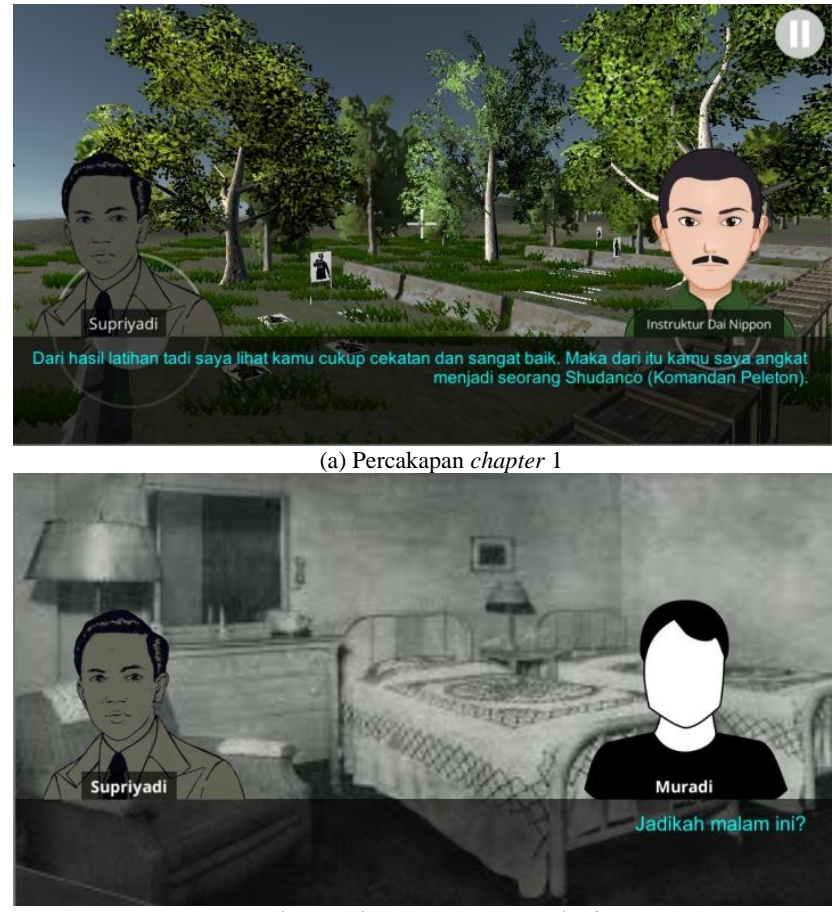

(b) Percakapan Pertemuan Rahasia

Gambar 11. Tampilan percakapan

Gambar 12 sampai dengan Gambar 15 merupakan tampilan-tampilan tahapan chapter 1 sampai dengan chapter 4, dimana pemain harus menyelesaikan tantangan chapter 1 untuk dapat masuk ke tantangan chapter 2, untuk masuk ke tantangan chapter 3 pemain harus menyelesaikan chapter 3, dan untuk masuk ke tantangan chapter 4 pemain harus menyelesaikan chapter 3 .

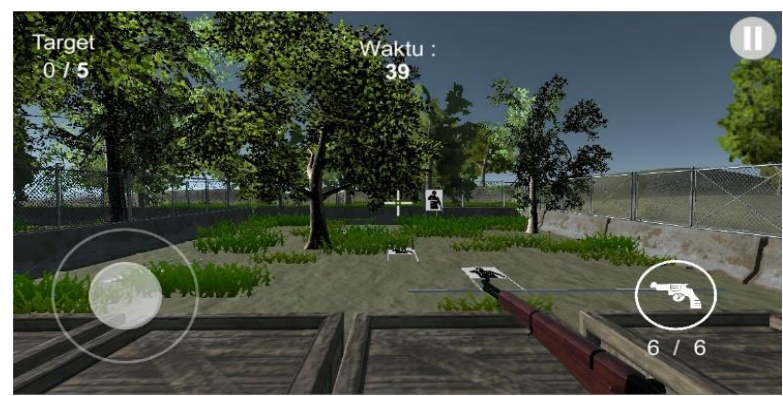

Gambar 12. Tampilan chapter 1

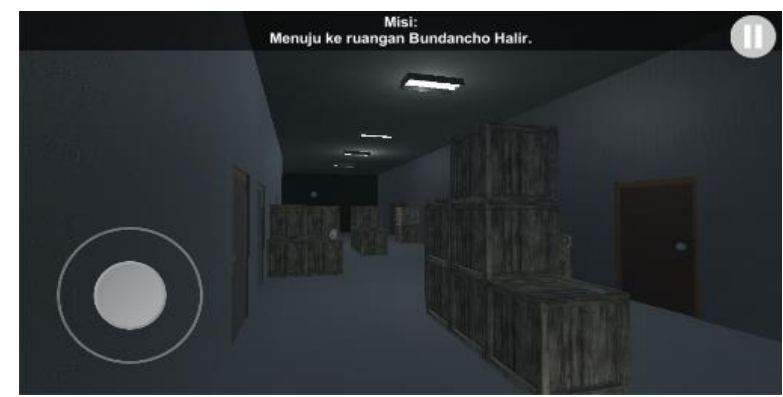

Gambar 13. Tampilan chapter 2 

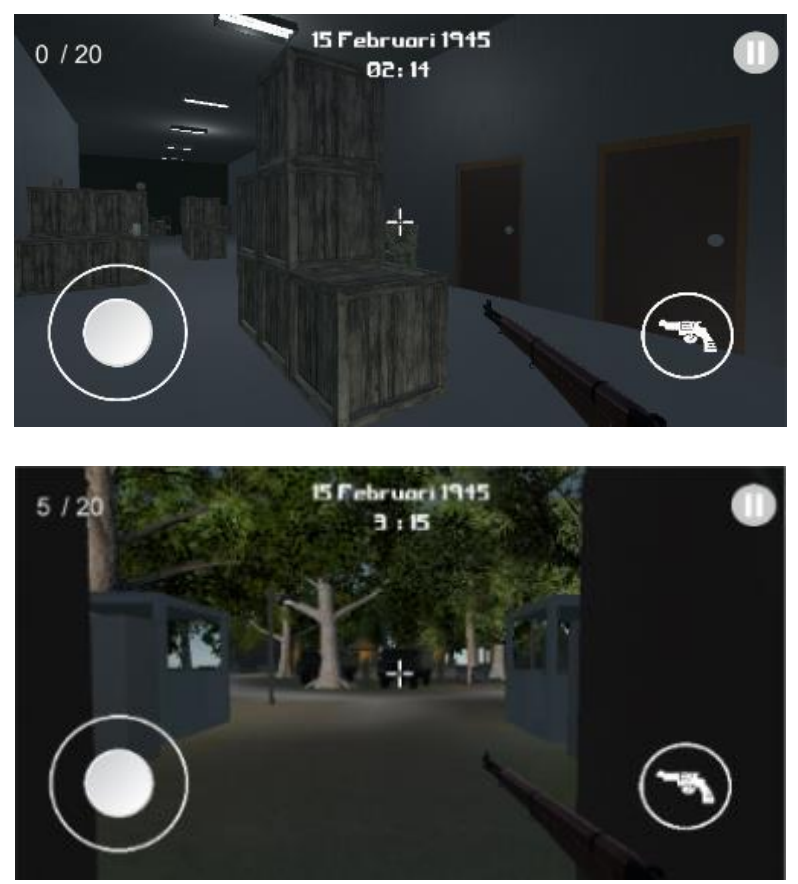

Gambar 14. Tampilan chapter 3
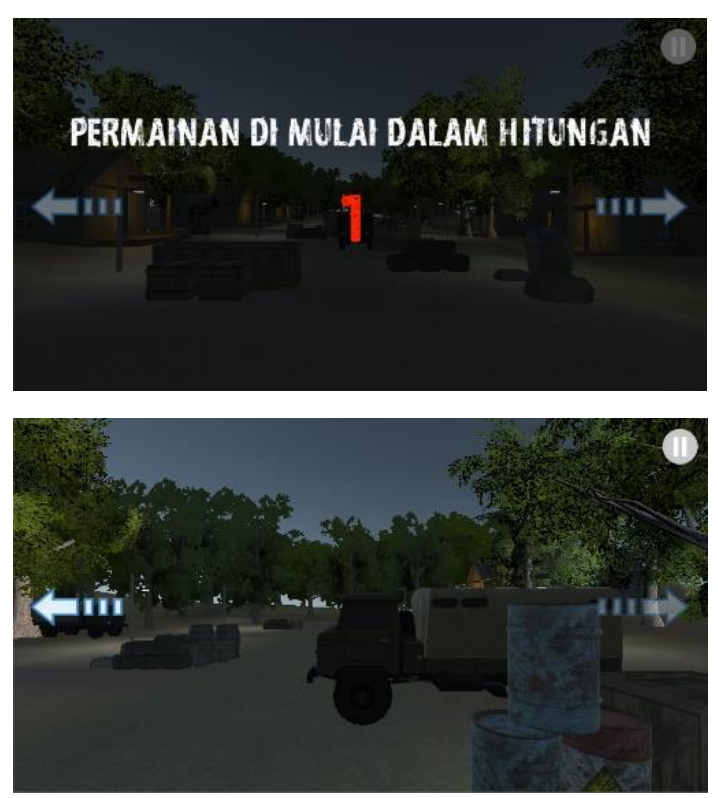

Gambar 15. Tampilan chapter 4

Gambar 16 merupakan tampilan atau tahapan chapter 4 yang menyajikan beberapa titik trigger yang yang berfungsi jika player mengenai trigger tersebut maka mobil akan berjalan untuk menghalangi player.

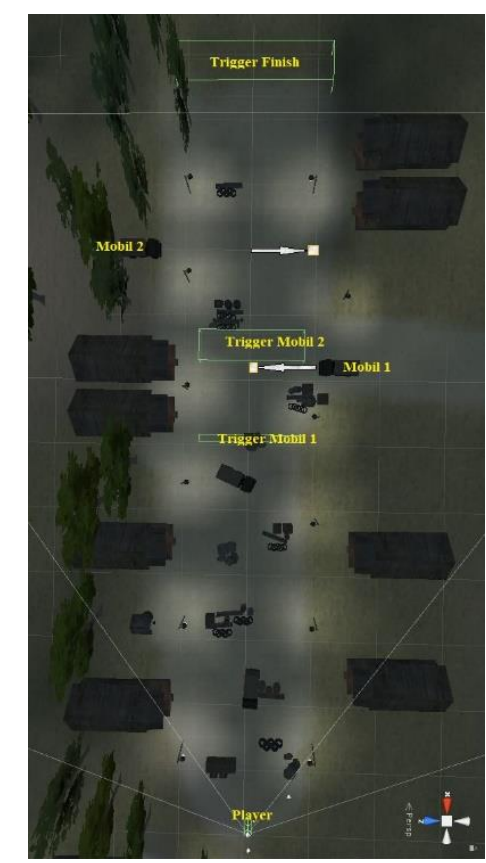

Gambar 16. Tampilan letak trigger chapter 4

Gambar 17 merupakan tampilan jika player telah berhasil menyelesaikan misi yang diberikan. Tampilan misi sukses dibuat agar player dapat mengetahui misi yang dilakukan telah berhasil.

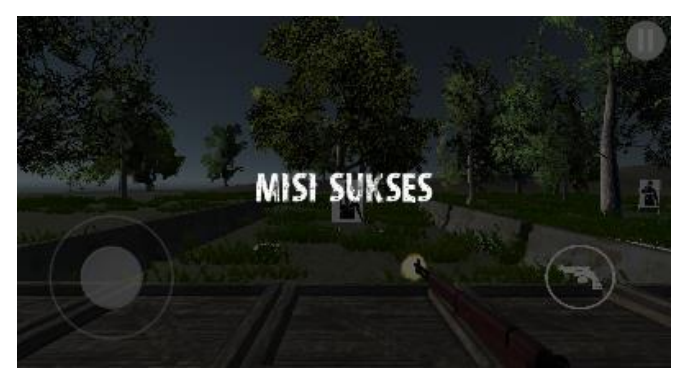

Gambar 17. Tampilan misi sukses chapter 1

Gambar 18 merupakan tampilan mini game. Mini game akan terbuka ketika pemain berhasil menyelesaikan chapter 4. Mini game ini dibuat untuk menguji materi sejarah yang dimasukkan ke dalam chapter 1 sampai chapter 4. Gambar 19 merupakan contoh tampilan ending scene. Akhir permainan akan dimulai dengan keterangan akhir cerita perlawanan Supriyadi (PETA di Blitar), animasi pembacaan teks proklamasi, pengangkatan Supriyadi sebagai pahlawan nasional dan kembalinya Leon ke dunia asal. 


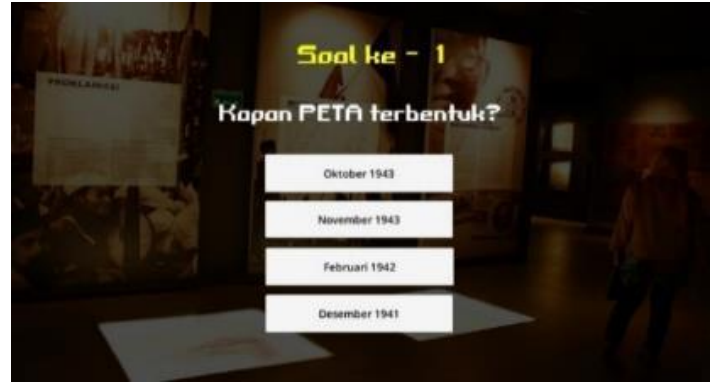

Gambar 18. Tampilan mini game pengujian materi pembelajaran

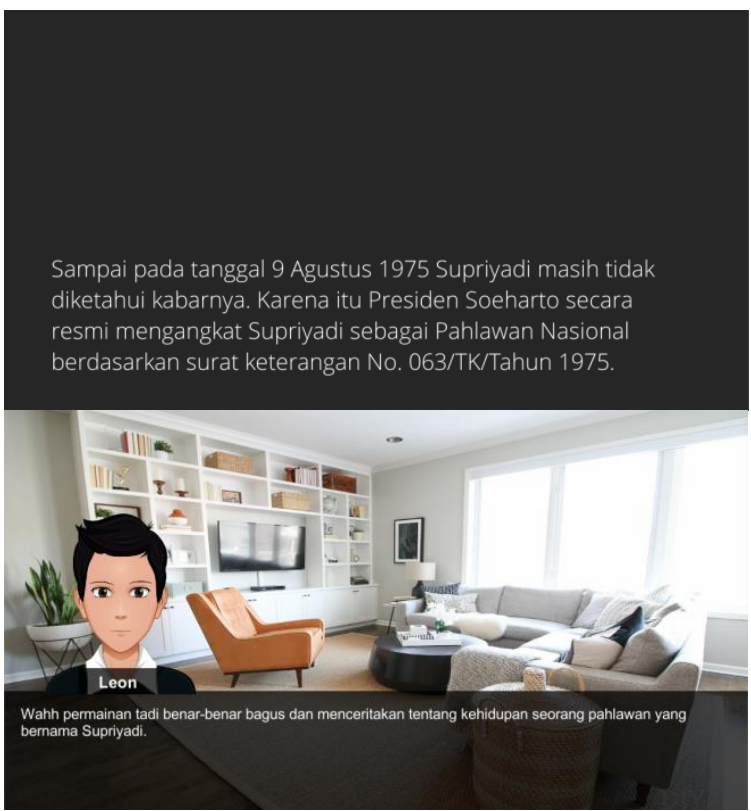

Gambar 19. Beberapa tampilan ending scene

\section{B. Pengujian dengan Unit Testing}

Pengujian dengan metode blackbox test yaitu pengujian terhadap edugame yang telah dibuat, dari pengujian yang dilakukan terhadap edugame ini didapat hasil semua fungsi yang diujikan lolos uji. Hasil beberapa pengujian unit testing dengan metode blackbox test dapat dilihat pada Tabel XI.

TABEL XI

PENGUJIAN UNIT TESTING

\begin{tabular}{|c|c|c|c|c|c|c|}
\hline \multirow{2}{*}{$\begin{array}{c}\text { Nama } \\
\text { Pengujian }\end{array}$} & \multirow[t]{2}{*}{ Tujuan } & \multirow[t]{2}{*}{ Skenario } & \multirow{2}{*}{$\begin{array}{l}\text { Hasil yang } \\
\text { diharapkan }\end{array}$} & \multicolumn{3}{|c|}{ Penguji } \\
\hline & & & & 1 & 2 & 3 \\
\hline $\begin{array}{l}\text { Menjalank } \\
\text { an tombol } \\
\text { tentang } \\
\text { kami }\end{array}$ & $\begin{array}{l}\text { Agar } \\
\text { player } \\
\text { dapat } \\
\text { mengeta } \\
\text { hui siapa } \\
\text { yang } \\
\text { membuat } \\
\text { game } \\
\text { tersebut. }\end{array}$ & $\begin{array}{l}\text { Menjalan } \\
\text { kan } \\
\text { tombol } \\
\text { tentang } \\
\text { kami }\end{array}$ & $\begin{array}{l}\text { Menampilka } \\
\mathrm{n} \text { identitas } \\
\text { pembuat } \\
\text { game. }\end{array}$ & Ok & Ok & Ok \\
\hline
\end{tabular}

\begin{tabular}{|c|c|c|c|c|c|c|}
\hline Nama & Tujuan & Skenario & Hasil yang & & engu & \\
\hline Pengujian & & & diharapkan & 1 & 2 & 3 \\
\hline $\begin{array}{l}\text { Menjalank } \\
\text { an tombol } \\
\text { mulai }\end{array}$ & \begin{tabular}{|l} 
Agar \\
player \\
dapat \\
memulai \\
ke \\
permaina \\
n. \\
\end{tabular} & $\begin{array}{l}\text { Menjalan } \\
\text { kan } \\
\text { tombol } \\
\text { mulai }\end{array}$ & $\begin{array}{l}\text { Menampilka } \\
\mathrm{n} \text { menu } \\
\text { chapter }\end{array}$ & Ok & Ok & Ok \\
\hline $\begin{array}{l}\text { Memilih } \\
\text { chapter }\end{array}$ & $\begin{array}{l}\text { Agar } \\
\text { player } \\
\text { dapat } \\
\text { memilih } \\
\text { chapter }\end{array}$ & \begin{tabular}{|l|} 
Memilih \\
chapter \\
yang \\
sudah \\
terbuka \\
dan \\
belum \\
terbuka
\end{tabular} & $\begin{array}{l}\text { Hanya dapat } \\
\text { memilih } \\
\text { chapter } \\
\text { yang } \\
\text { terbuka }\end{array}$ & Ok & Ok & Ok \\
\hline $\begin{array}{l}\text { Memainka } \\
\mathrm{n} \text { game } \\
\text { chapter } 1\end{array}$ & $\begin{array}{l}\text { Memaink } \\
\text { an } \\
\text { permaina } \\
\text { n sesuai } \\
\text { dengan } \\
\text { misi } \\
\text { yang } \\
\text { diberikan }\end{array}$ & $\begin{array}{l}\text { Memaink } \\
\text { an game } \\
\text { untuk } \\
\text { dimenan } \\
\text { gkan dan } \\
\text { dikalahk } \\
\text { an }\end{array}$ & $\begin{array}{l}\text { Target } \\
\text { muncul } \\
\text { secara } \\
\text { random, } \\
\text { penambahan } \\
\text { jumlah } \\
\text { target } \\
\text { terkena, } \\
\text { waktu } \\
\text { berjalan, } \\
\text { dan } \\
\text { penguranga } \\
\text { n jumlah } \\
\text { peluru jika } \\
\text { menekan } \\
\text { tombol } \\
\text { tembak } \\
\end{array}$ & Ok & Ok & Ok \\
\hline $\begin{array}{l}\text { Memainka } \\
\mathrm{n} \text { game } \\
\text { chapter } 2\end{array}$ & $\begin{array}{l}\text { Memaink } \\
\text { an } \\
\text { permaina } \\
\text { n sesuai } \\
\text { dengan } \\
\text { misi } \\
\text { yang } \\
\text { diberikan }\end{array}$ & $\begin{array}{l}\text { Memaink } \\
\text { an game } \\
\text { untuk } \\
\text { dimenan } \\
\text { gkan dan } \\
\text { dikalahk } \\
\text { an }\end{array}$ & \begin{tabular}{|l} 
Jika terlihat \\
oleh tentara \\
Jepang \\
maka game \\
over, jika \\
posisi \\
player di \\
tutupi oleh \\
benda maka \\
player tidak \\
terlihat.
\end{tabular} & Ok & Ok & Ok \\
\hline $\begin{array}{l}\text { Memainka } \\
\mathrm{n} \text { game } \\
\text { chapter } 3\end{array}$ & $\begin{array}{l}\text { Memaink } \\
\text { an } \\
\text { permaina } \\
\text { n sesuai } \\
\text { dengan } \\
\text { misi } \\
\text { yang } \\
\text { diberikan }\end{array}$ & $\begin{array}{l}\text { Memaink } \\
\text { an game } \\
\text { untuk } \\
\text { dimenan } \\
\text { gkan dan } \\
\text { dikalahk } \\
\text { an }\end{array}$ & $\begin{array}{l}\text { Penambaha } \\
\mathrm{n} \text { jumlah } \\
\text { target } \\
\text { terkena, } \\
\text { tentara } \\
\text { Jepang } \\
\text { menembak } \\
\text { jika melihat } \\
\text { player, jika } \\
\text { game over } \\
\text { dapat } \\
\text { respawn } \\
\text { pada } \\
\text { checkpoint. }\end{array}$ & Ok & Ok & Ok \\
\hline $\begin{array}{l}\text { Memainka } \\
\text { n game }\end{array}$ & $\begin{array}{l}\text { Memaink } \\
\text { an }\end{array}$ & $\begin{array}{l}\text { Memaink } \\
\text { an game }\end{array}$ & $\begin{array}{l}\text { Player } \\
\text { berlari }\end{array}$ & Ok & Ok & Ok \\
\hline
\end{tabular}




\begin{tabular}{|c|c|c|c|c|c|c|}
\hline \multirow{2}{*}{$\begin{array}{c}\text { Nama } \\
\text { Pengujian }\end{array}$} & \multirow[t]{2}{*}{ Tujuan } & \multirow[t]{2}{*}{ Skenario } & \multirow{2}{*}{$\begin{array}{l}\text { Hasil yang } \\
\text { diharapkan }\end{array}$} & \multicolumn{3}{|c|}{ Penguji } \\
\hline & & & & 1 & 2 & 3 \\
\hline chapter 4 & \begin{tabular}{|l} 
permaina \\
$\mathrm{n}$ sesuai \\
dengan \\
misi \\
yang \\
diberikan
\end{tabular} & $\begin{array}{l}\text { untuk } \\
\text { dimenan } \\
\text { gkan dan } \\
\text { dikalahk } \\
\text { an }\end{array}$ & $\begin{array}{l}\text { otomatis, } \\
\text { mobil } \\
\text { berjalan jika } \\
\text { player } \\
\text { mendekat, } \\
\text { jika } \\
\text { menabrak } \\
\text { sesuatu } \\
\text { maka game } \\
\text { over. }\end{array}$ & & & \\
\hline Game over & $\begin{array}{l}\text { Memberi } \\
\text { tahu } \\
\text { player } \\
\text { telah } \\
\text { gagal } \\
\text { menyeles } \\
\text { aikan } \\
\text { misi }\end{array}$ & $\begin{array}{l}\text { Mencoba } \\
\text { memberit } \\
\text { ahu } \\
\text { player } \\
\text { kondisi } \\
\text { game } \\
\text { over }\end{array}$ & \begin{tabular}{|l} 
Menampilka \\
$\mathrm{n}$ menu \\
game over \\
dengan 3 \\
tombol \\
yaitu \\
tombol coba \\
lagi, tombol \\
menu \\
utama, dan \\
tombol \\
keluar \\
\end{tabular} & Ok & Ok & $\mathrm{Ok}$ \\
\hline $\begin{array}{l}\text { Menjalank } \\
\text { an tombol } \\
\text { coba lagi }\end{array}$ & \begin{tabular}{|l} 
Memulai \\
ulang \\
game \\
yang \\
telah \\
gagal \\
diselesai \\
kan
\end{tabular} & \begin{tabular}{|l} 
Mencoba \\
lagi \\
game \\
untuk \\
dimenan \\
gkan
\end{tabular} & $\begin{array}{l}\text { Menampilka } \\
\mathrm{n} \text { game } \\
\text { yang belum } \\
\text { terselesaika } \\
\mathrm{n} .\end{array}$ & Ok & Ok & Ok \\
\hline $\begin{array}{l}\text { Menjalank } \\
\text { an tombol } \\
\text { pause }\end{array}$ & $\begin{array}{l}\text { Player } \\
\text { dapat } \\
\text { menghen } \\
\text { tikan } \\
\text { permaina } \\
\text { n } \\
\text { sementar } \\
\text { a. }\end{array}$ & $\begin{array}{l}\text { Membuk } \\
\text { a menu } \\
\text { pause }\end{array}$ & \begin{tabular}{|l} 
menampilka \\
n menu \\
pause \\
dengan \\
empat \\
pilihan \\
tombol \\
yaitu \\
tombol \\
lanjutkan, \\
tombol \\
pengaturan, \\
tombol \\
menu \\
utama, dan \\
keluar \\
\end{tabular} & Ok & Ok & Ok \\
\hline $\begin{array}{l}\text { Menjalank } \\
\text { an tombol } \\
\text { keluar }\end{array}$ & \begin{tabular}{|l} 
Agar \\
player \\
dapat \\
keluar \\
dari \\
aplikasi \\
permaina \\
n
\end{tabular} & $\begin{array}{l}\text { Menekan } \\
\text { tombol } \\
\text { keluar }\end{array}$ & $\begin{array}{l}\text { Keluar dari } \\
\text { aplikasi } \\
\text { permainan }\end{array}$ & Ok & Ok & $\mathrm{Ok}$ \\
\hline
\end{tabular}

Berdasarkan hasil 16 pengujian pada Tabel XI dan diuji oleh tiga orang expert di bidang game dapat diketahui persentase ketercapaian sebagai berikut :

$$
\begin{aligned}
& \text { Tercapai }=\frac{48}{48} \times 100 \%=100 \% \\
& \text { Gagal }=\frac{0}{48} \times 100 \%=0 \%
\end{aligned}
$$

Setelah didapatkan nilai kuantitatif kemudian di koversikan menjadi nilai kualitatif berdasarkan skala penilaian. Maka hasil pengujian blackbox menunjukan interprestasi "Sangat Layak".

\section{Pengujian dengan System Testing}

Pengujian dilakukan menggunakan metode stress testing untuk menguji aspek realibilitas dan instability test untuk menguji aspek kompatibel.

1. Install and Launch Testing

Pengujian dilakukan pada enam macam perangkat yang berbeda. Pengujian dilakukan dengan cara observasi dengan melihat langsung pada smartphone yang berbeda. Hasil pengujian dapat dilihat pada Tabel XII.

TABEL XII

PENGUJIAN INSTALL AND LAUNCH

\begin{tabular}{|l|l|l|}
\hline \multirow{2}{*}{ No } & Faktor Uji & Hasil Uji \\
\cline { 2 - 3 } & Sistem Operasi & \multicolumn{2}{|l|}{} \\
\hline 1 & Android Marshmellow 6.0 & Sukses \\
\hline 2 & Android Nougat 7.1.0 & Sukses \\
\hline 3 & Android Oreo 8.1.0 & Sukses \\
\hline & Resolusi & \\
\hline 4 & $720 \times 1280$ & Sukses \\
\hline 5 & $1080 \times 1920$ & Sukses \\
\hline 6 & $1080 \times 2340$ & Sukses \\
\hline
\end{tabular}

2. Stress Testing

Tahapan peristiwa input atau touch player yang dilakukan secara acak dan berulang selama lima kali untuk menguji aplikasi dibawah tekanan. Hasil stress testing yang dilakukan pada 6 macam perangkat yang berbeda dapat dilihat pada Tabel XIII.

TABEL XIII

PENGUJIAN STRESS TESTING

\begin{tabular}{|l|l|l|l|l|l|}
\hline No & $\begin{array}{l}\text { Nama } \\
\text { Perang } \\
\text { kat }\end{array}$ & $\begin{array}{l}\text { Resolusi } \\
\text { layar }\end{array}$ & $\begin{array}{l}\text { Nama } \\
\text { Prosesor }\end{array}$ & $\begin{array}{l}\text { Memory } \\
\text { hasil }\end{array}$ & Hasil \\
\hline 1 & $\begin{array}{l}\text { Xiaomi } \\
\text { Redmi } \\
\text { Note } 4\end{array}$ & $\begin{array}{l}1080 \mathrm{x} \\
1920\end{array}$ & $\begin{array}{l}\text { Mediatek } \\
\text { Helio } \\
\text { X20 }\end{array}$ & $3 \mathrm{~Gb}$ & $\begin{array}{l}\text { Tidak } \\
\text { ada } \\
\text { bugs }\end{array}$ \\
\hline 2 & $\begin{array}{l}\text { Oppo } \\
\text { F7 }\end{array}$ & $\begin{array}{l}2280 \mathrm{x} \\
1080\end{array}$ & $\begin{array}{l}\text { Mediatek } \\
\text { Helio } \\
\text { P60 }\end{array}$ & $3 \mathrm{~Gb}$ & $\begin{array}{l}\text { Tidak } \\
\text { ada } \\
\text { bugs }\end{array}$ \\
\hline 3 & $\begin{array}{l}\text { Xiaomi } \\
\text { Redmi } \\
\text { Note } 4 \mathrm{x}\end{array}$ & $\begin{array}{l}1920 \mathrm{x} \\
1080\end{array}$ & $\begin{array}{l}\text { Snapdrag } \\
\text { on 625 }\end{array}$ & $6 \mathrm{~Gb}$ & $\begin{array}{l}\text { Tidak } \\
\text { ada } \\
\text { bugs }\end{array}$ \\
\hline 4 & $\begin{array}{l}\text { Oppo } \\
\text { F9 }\end{array}$ & $\begin{array}{l}2340 \mathrm{x} \\
1080\end{array}$ & $\begin{array}{l}\text { Mediatek } \\
\text { Helio } \\
\text { P60 }\end{array}$ & 4 Gb & $\begin{array}{l}\text { Tidak } \\
\text { ada } \\
\text { bugs }\end{array}$ \\
\hline
\end{tabular}




\begin{tabular}{|l|l|l|l|l|l|}
\hline No & $\begin{array}{l}\text { Nama } \\
\text { Perang } \\
\text { kat }\end{array}$ & $\begin{array}{l}\text { Resolusi } \\
\text { layar }\end{array}$ & $\begin{array}{l}\text { Nama } \\
\text { Prosesor }\end{array}$ & $\begin{array}{l}\text { Memory } \\
\text { hasil }\end{array}$ & Hasil \\
\hline 5 & $\begin{array}{l}\text { Asus } \\
\text { Zenfon } \\
\text { e 2 }\end{array}$ & $\begin{array}{l}720 \mathrm{x} \\
1280\end{array}$ & $\begin{array}{l}\text { Intel(R) } \\
\text { tom(TM) } \\
\text { CPU } \\
\text { Z2560 }\end{array}$ & $2 \mathrm{~Gb}$ & $\begin{array}{l}\text { Tidak } \\
\text { ada } \\
\text { bugs }\end{array}$ \\
\hline 6 & $\begin{array}{l}\text { Samsun } \\
\text { g S7 }\end{array}$ & $\begin{array}{l}2560 \mathrm{x} \\
1440\end{array}$ & $\begin{array}{l}\text { Snapdrag } \\
\text { on } 820\end{array}$ & $4 \mathrm{~Gb}$ & $\begin{array}{l}\text { Tidak } \\
\text { ada } \\
\text { bugs }\end{array}$ \\
\hline
\end{tabular}

Berdasarkan Tabel XII dan Tabel XIII yang bersumber dari hasil observasi dengan melihat dan mencoba langsung dari smartphone yang berbeda menunjukkan bahwa selama pengujian, game dapat berjalan dengan baik, tidak mengalami error dan tidak ada menunjukan penurunan performa yang menganggu aplikasi, sehingga dapat disimpulkan bahwa tingkat sukses dari hasil pengujian realibilitas dengan menggunakan stress testing adalah sebesar $100 \%$.

$$
\begin{aligned}
& \text { Tercapai }=\frac{12}{12} \times 100 \%=100 \% \\
& \text { Gagal }=\frac{0}{12} \times 100 \%=0 \%
\end{aligned}
$$

Setelah didapatkan nilai kuantitatif kemudian dikonversikan menjadi nilai kualitatif berdasarkan skala penilaian. Maka hasil pengujian system testing menunjukkan interpretasi "Sangat Layak".

\section{Pengujian Acceptance Testing}

1. Expert Judgement

Expert judgement adalah pengujian yang dilakukan dengan meminta pendapat atau pertimbangan kepada ahli atau orang yang telah berpengalaman dalam bidang tertentu. Pengujian akan dilakukan kepada tiga orang ahli. Pengujian dilakukan menggunakan kuesioner terhadap tiga orang ahli yaitu : Ahli Media, ahli materi, dan ahli game. Hasil dari pengujian tersebut terdapat pada Tabel XIV.

TABEL XIV

\begin{tabular}{|c|c|c|c|}
\hline Nama & \multicolumn{3}{|c|}{ Ahmad Farisi, M.Kom } \\
\hline Keahlian & \multicolumn{3}{|c|}{ Mobile and Web Programming } \\
\hline Aspek Uji & \multicolumn{3}{|c|}{ Interface, content, dan playability } \\
\hline Jumlah Skor & $\begin{array}{l}\text { Skor } \\
\text { Maksimal }\end{array}$ & Persentase & Keterangan \\
\hline 70 & 75 & $93 \%$ & Sangat Baik \\
\hline Nama & \multicolumn{3}{|c|}{ Kgs. Achmad Siddik, S.Kom } \\
\hline Keahlian & \multicolumn{3}{|c|}{ Mobile and Game Programming } \\
\hline Aspek Uji & \multicolumn{3}{|c|}{ Interface, content, dan playability } \\
\hline Jumlah Skor & $\begin{array}{l}\text { Skor } \\
\text { Maksimal }\end{array}$ & Persentase & Keterangan \\
\hline 65 & 75 & $87 \%$ & Sangat Baik \\
\hline Nama & \multicolumn{3}{|l|}{ Bhagaskara } \\
\hline
\end{tabular}

HASIL PENGUJIAN EXPERT JUDGEMENT

\begin{tabular}{|l|l|c|l|}
\hline Keahlian & \multicolumn{3}{|l|}{ Game Programming } \\
\hline Aspek Uji & \multicolumn{3}{l|}{ Interface, content, dan playability } \\
\hline Jumlah Skor & $\begin{array}{l}\text { Skor } \\
\text { Maksimal }\end{array}$ & Persentase & Keterangan \\
\hline 62 & 75 & $83 \%$ & Sangat Baik \\
\hline
\end{tabular}

Berdasarkan pengujian oleh tiga expert pada Tabel XIV didapatkan total persentase $87 \%$ sehingga dikategorikan "Sangat Baik".

\section{Playability Testing}

Menurut Rifai hasil pengujian aplikasi nantinya akan didapatkan skor tiap pengujian masing-masing meliputi unit testing, system testing, dan acceptance testing kemudian dihitung rata-rata instrumen dengan rumus [19] :

$$
\begin{aligned}
& \bar{x}=\frac{\sum x}{n} \\
& \bar{x}=\text { skor rata-rata } \\
& \sum x \quad=\text { skor total item } \\
& =\text { jumlah item }
\end{aligned}
$$

Setelah mendapatkan skor rata-rata masing-masing pengujian kemudian menghitung persentase kelayakan dengan rumus berikut ini :

$$
\text { kelayakan }(\%)=\frac{\text { skor } y \text { ang diobservasi }}{\text { skor yang diharapkan }} \times 100 \%
$$

Hasil dari persentase tersebut kemudian dicocokan dengan predikat skala likert pada Tabel XV.

TABEL XV

SKALA PENILAIAN LIKERT

\begin{tabular}{|l|l|l|}
\hline No & Presentase & Interpretasi \\
\hline 1 & $0 \%-20 \%$ & Sangat Tidak Layak \\
\hline 2 & $21 \%-40 \%$ & Tidak Layak \\
\hline 3 & $41 \%-60 \%$ & Cukup Layak \\
\hline 4 & $61 \%-80 \%$ & Layak \\
\hline 5 & $81 \%-100 \%$ & Sangat Layak \\
\hline
\end{tabular}

Pengujian tampilan antarmuka permainan, tingkat kepuasan dalam mencoba permainan, dan nilai edukasi pada permainan dengan menyebarkan kuesioner kepada murid SMA kelas XI dengan mengambil responden sebanyak 62 siswa. Keterangan pilihan jawaban berupa $\mathbf{1}$ untuk STS (Sangat Tidak Setuju), 2 untuk TS (Tidak Setuju), 3 untuk N (Netral), 4 untuk S (Setuju) dan 5 untuk SS (Sangat Setuju).

Tabel XVI sampai dengan Tabel XVII menunjukkan pertanyaan pada kuesioner mengenai tampilan antarmuka permainan, nilai edukasi pada permainan, dan kepuasan pengguna dalam mencoba permainan. Hasil diperlihatkan pada grafik Gambar 20 sampai dengan Gambar 22.

TABEL XVI

PERTANYAAN TAMPILAN ANTARMUKa PERMAINAN

\begin{tabular}{|l|c|c|c|c|c|c|}
\hline No. & Pertanyaan & $\mathbf{1}$ & $\mathbf{2}$ & $\mathbf{3}$ & $\mathbf{4}$ & $\mathbf{5}$ \\
\hline 1. & Apakah tampilan pada & & & 4 & 34 & 24 \\
\hline
\end{tabular}




\begin{tabular}{|l|l|c|c|c|c|c|}
\hline No. & \multicolumn{1}{|c|}{ Pertanyaan } & $\mathbf{1}$ & $\mathbf{2}$ & $\mathbf{3}$ & $\mathbf{4}$ & $\mathbf{5}$ \\
\hline & permainan mudah dimengerti? & & & & & \\
\hline 2. & $\begin{array}{l}\text { Apakah tata letak tombol dan } \\
\text { pilihan menu pada permainan } \\
\text { telah sesuai? }\end{array}$ & & 3 & 6 & 32 & 21 \\
\hline 3. & $\begin{array}{l}\text { Apakah desain edugame } \\
\text { menarik? }\end{array}$ & & & 4 & 39 & 19 \\
\hline 4. & $\begin{array}{l}\text { Apakah tulisan yang ada pada } \\
\text { permainan dapat dibaca dengan } \\
\text { jelas? }\end{array}$ & & & & 38 & 24 \\
\hline
\end{tabular}

\section{Tampilan Antarmuka Permainan}

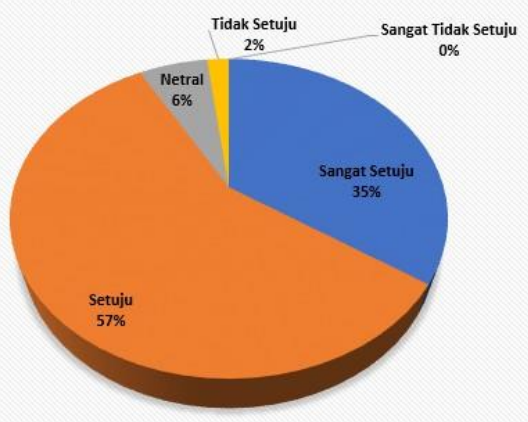

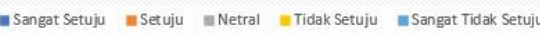

Gambar 20. Grafik kuesioner tampilan antarmuka

TABEL XVII

PertanyaAn Nilai Edukasi Pada Permainan

\begin{tabular}{|c|c|c|c|c|c|c|}
\hline No. & Pertanyaan & 1 & 2 & 3 & 4 & 5 \\
\hline 1. & $\begin{array}{l}\text { Apakah melalui permainan ini } \\
\text { dapat membantu anak untuk } \\
\text { lebih mudah mempelajari } \\
\text { pelajaran sejarah perlawanan } \\
\text { PETA Blitar? }\end{array}$ & & & 4 & 35 & 24 \\
\hline 2. & $\begin{array}{l}\text { Apakah melalui permainan ini } \\
\text { dapat membantu mengenalkan } \\
\text { tokoh Shodanco Supriyadi yang } \\
\text { memperjuangkan kebebasan } \\
\text { rakyat Indonesia terhadap } \\
\text { Jepang? }\end{array}$ & & & 4 & 32 & 26 \\
\hline 3. & $\begin{array}{l}\text { Apakah melalui permainan ini } \\
\text { dapat membantu anda untuk } \\
\text { menjadi tahu dan paham } \\
\text { dengan pengetahuan tentang } \\
\text { sejarah perlawanan } \\
\text { Blitar? }\end{array}$ & & & 4 & 34 & 24 \\
\hline
\end{tabular}

Nilai Edukasi Pada Permainan

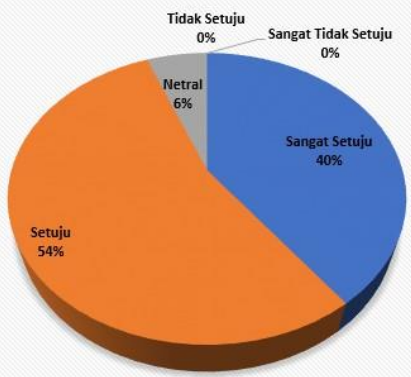

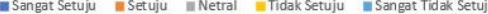

Gambar 21. Grafik kuesioner nilai edukasi pada permainan

TABEL XVIII

Pertanyaan Kepuasan Pengguna dalam Mencoba Permainan

\begin{tabular}{|c|l|c|c|c|c|c|}
\hline No. & \multicolumn{1}{|c|}{ Pertanyaan permainan ini } & $\mathbf{1}$ & $\mathbf{2}$ & $\mathbf{3}$ & $\mathbf{4}$ & $\mathbf{5}$ \\
\hline 1. & $\begin{array}{l}\text { Apakah } \\
\text { mendidik dan menyenangkan? }\end{array}$ & & 3 & 39 & 20 \\
\hline 2. & $\begin{array}{l}\text { Apakah informasi yang ada } \\
\text { pada permainan dapat } \\
\text { menambah pengetahuan? }\end{array}$ & & 4 & 34 & 24 \\
\hline 3. & $\begin{array}{l}\text { Apakah tampilan yang ada di } \\
\text { dalam permainan sangat } \\
\text { menarik? }\end{array}$ & 3 & 4 & 34 & 21 \\
\hline 4. & $\begin{array}{l}\text { Apakah area-area permainan } \\
\text { yang ada di dalam permainan } \\
\text { sudah baik? }\end{array}$ & & 4 & 36 & 22 \\
\hline 5. & $\begin{array}{l}\text { Apakah aplikasi ini dapat } \\
\text { menjadi alternatif } \\
\text { pembelajaran? }\end{array}$ & & 1 & 34 & 27 \\
\hline 6. & $\begin{array}{l}\text { Apakah misi-misi yang ada } \\
\text { pada permainan menantang dan } \\
\text { mudah dimengerti? }\end{array}$ & & 3 & 39 & 20 \\
\hline 7. & $\begin{array}{l}\text { Apakah tingkat kesulitan pada } \\
\text { permainan sudah sesuai? }\end{array}$ & & 7 & 38 & 17 \\
\hline
\end{tabular}

Kepuasan Pengguna Dalam Mencoba Permainan Tidak Setuju Sangat Tidak Setuju
$1 \%$ 0\%

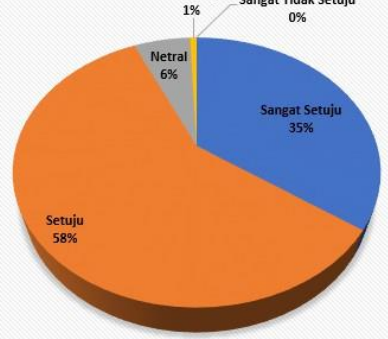

Gambar 22. Grafik kepuasan pengguna 


\section{IV.PENUTUP}

\section{A. Kesimpulan}

Berdasarkan hasil perancangan game yang telah dilakukan, game ini memiliki empat chapter yaitu latihan menembak, menghindari tentara Jepang, perlawanan terhadap tentara Jepang, dan pelarian. Dari hasil pengujian yang telah dilakukan dari 62 anak Sekolah Menengah Atas didapatkan hasil $92 \%$ tertarik dengan tampilan antarmuka permainan, 94\% menilai nilai edukasi yang dimasukkan membantu dalam pembelajaran sejarah, dan $93 \%$ puas dalam mencoba permainan, maka dapat diambil kesimpulan bahwa melalui game edukasi ini siswa dapat mempelajari sejarah tokoh Supriyadi yang berperan penting dalam memperjuangkan kebebasan rakyat Indonesia terhadap Jepang.

\section{B. Saran}

Dalam perancangan game ini masih terdapat banyak hal yang dapat dikembangkan lebih jauh lagi. Saran dan pemikiran untuk pengembangan ke depan antara lain berupa adanya pemberian score point kepada pemain pada chapter 1 game History of Shodanco Supriyadi, penambahan varian senjata, adanya opsi untuk mendapatkan reward koin yang dapat digunakan untuk melakukan pembelian senjata. Selain itu, disarankan pengembangan game History of Shodanco Supriyadi pada platform lain dengan sistem operasi yang berbeda seperti iOS, Windows Phone, dll serta penelitian lebih lanjut tentang aspek kemampuan untuk dimainkan untuk berbagai platform game.

\section{DAFTAR PUSTAKA}

[1] Kominfo. Survey Penggunaan TIK 2017: Serta Implikasinya terhadap Aspek Sosial Budaya Masyarakat. Jakarta: Kementerian Komunikasi dan Informatika Republik Indonesia, 2017.

[2] M. Ridoi. Cara Mudah Membuat Game Edukasi dengan Construct 2. Malang, Indonesia: Sagusagame, 2018.

[3] D. Fidiyanto, T. Listyorini, \& M. Nurkamid. "Game sejarah perjuangan kapitan patimura berbasis android", Prosiding SNATIF, vol 2, 2015, pp. 21-28.
[4] R. Priyana \& E.T.E. Handayani. "Perancangan game "heroes Surabaya" sebagai edukasi pengetahuan sejarah menggunakan algoritma BFS berbasis android", Jurnal Informatika Merdeka Pasuruan, vol 4, no 1, pp. 5, Maret 2019.

[5] S. Sugiyanto, A.I. Waskito. "Game edukasi pahlawan Indonesia", Jurnal Media Pratama, vol 13, no 2, pp.5-11, 2019.

[6] A.K. Aprilia, Sugiyanto, \& S. Handayani. "The Role of Nahdlatul Ulama on Indonesian national movement on 1926 - 1945", Jurnal Historica, vol. 1, no. 2, pp. 261, 2017.

[7] M. Adil. EPPS: Sejarah SMA/MA kelas X (jilid 1), Jakarta, Indonesia: Erlangga, 2016.

[8] M. Arroyan, \& Yoannita. "Rancang bangun aplikasi edugame sejarah walisongo (Sunan Kalijaga) dengan unity 3d", e-prints skripsi, STMIK GI MDP, 2015.

[9] L.Y.D. Pangau, S.T.G. Kaunang, \& A.S.M. Lumenta. "Game based education: pengenalan peristiwa sejarah permesta di Minahasa", Jurnal Teknik Informatika Universitas Sam Ratulangi, vol. 14, no.2, pp. 203-209, Juni 2019.

[10] R.A. Prasetya, H. Sulistyanto. "Rancang bangun permainan edukatif pengenalan tokoh pahlawan nasional untuk anak". $e$ prints skripsi, Universitas Muhammadiyah Surakarta, 2017

[11] A. Setiawan, R. Kridalukmana, I. P. Windasari. "Pengembangan permainan edukatif pahlawan nasional berbasis android", Jurnal Teknologi dan Sistem Komputer, vol. 3, no. 3, pp. 393, 2015. https://doi.org/10.14710/jtsiskom.3.3.2015.393-398

[12] R. Satria, W. Silfianti. "Android-based game platformer of the Indonesian hero using unity", Internasional Journal of Computer Engineering and Applications, vol. X, no. I, pp. 67-74, 2016.

[13] M.D. Dickey. Aesthetics and Design for Game-Based Learning, New York: Routledge, 2015.

[14] R. Roedavan. Unity Tutorial Game Engine, Bandung, Indonesia: Informatika, 2014.

[15] R.A. Sukamto, \& M. Shalahuddin, Rekayasa Perangkat Lunak Terstruktur dan Berorientasi Objek, Bandung, Indonesia: Informatika, 2013.

[16] Mirnawati. Kumpulan Pahlawan Indonesia, Jakarta, Indonesia: Swadaya Grup, 2012

[17] H. Kurniawan. (2016) "Misteri hilangnya Supriyadi dan pemberontakan PETA". [Online]. Tersedia: https://daerah.sindonews.com/read/1088603/29/misteri-hilangnyasupriyadi-dan-pemberontakan-peta-1456486151/.

[18] B. T. Wardaya. Mencari Supriyadi Kesaksian Pembantu Utama Bung Karto, Yogyakarta, Indonesia: Galangpress, 2008.

[19] W. A. Rifai. "Pengembangan game edukasi lingkungan berbasis android”, e-prints skripsi, Universitas Negeri Yogyakarta, 2015. 